\title{
2021-2027 Çok Yıllı Mali Çerçevesi: Avrupa Birliği’nde Güncel Zorlukların Bütçe Önceliklerine Yansımaları
}

\section{Multiannual Financial Framework for 2021-2027: The Reflections of Current Challenges in European Union on Budget Priorities}

\author{
Çağdaş CENGİZ, Türkiye, cagdascengiz1@ @otmail.com \\ Orcid No: 0000-0002-7606-5842 \\ Adem KURTAR, Dokuz Eylül Üniversitesi, Türkiye, adem.kurtar@deu.edu.tr \\ Orcid No: 0000-0002-0441-9250
}

\begin{abstract}
Öz: Bu çalı̧̧mada amaç, Avrupa Birliği bütçesine yansıyan yeni dönemsel öncelikleri ve bu öncelikleri koşullandıran güncel zorlukları dikkate alarak, 2021-2027 Çok Ylll Mali Çerçevesi’ni analiz etmektir. Bu doğrultuda, konuya ilişkin başta Avrupa Komisyonu olmak üzere resmi kurumlara ait asli metinler, değerlendirmeler, raporlar ve tamamlayıcı belge ve bağıtların yanı sıra resmi verilerin içeriği, sistematik olarak incelenmek ve yorumlanmak suretiyle analiz edilmiştir. Yapıst ve evrimi itibariyle kendine özgü bir bütünleşme örneği olan Avrupa Birliği'nin, tüm bileşenlerine ve politikalarına işlemiş olan bu özgünlüğü bütçesine de yansımıştır. Avrupa Birliği'nin bir nevi yeniden dağıtım mekanizması olan bütçesi, gerek Avrupa bütünleşmesinin dinamikleriyle, gerekse politik öncelikleriyle iç içe geçmiş bir gelişsim çizgisi izlemişstir. Topluluğun ilk dönemlerinden günümüze kadar geçen süreçte Avrupa Birliği, temel stratejik söylem ve politikaların korumakla birlikte, her bir mali döneme yanslyan küresel ve bölgesel gelişmelerin etkisini dönemsel önceliklerine aktarmak suretiyle değișmis ve dönüsmüstür. Mevcut bütçe dönemi (2014-2020) kaçinllmaz olarak küresel finans krizinin ve Euro Alanı Krizi'nin gölgesinde şekillenirken, 2021-2027 bütçesi ise ekonomik boyutun yanı sira bölgesel ve küresel düzeyde derinleşen siyasi, sosyal ve çevresel krizlerin çözümüne yönelik önlemleri önceleyerek tasarlanmıştır. Avrupa Birliği'nin yeni mali döneminde, güncel zorluklarla bașa çıkabilmek için belirlenen öncelikler, bütçedeki fonların yapısını, büyüklügünü ve tahsisini de önemli oranda etkilemisțtir. Böylece "Koruyan, Güçlendiren ve Savunan bir Birlik için Modern bir Bütçe” söylemiyle başlayan yeni dönem, başlıkların ve programların uygulamada sonuç verebilmesini, diğer bir deyișle verimliliği merkeze alarak planlanmıştır. Bununla birlikte bu tasarı, Birlik açısından güncel gelișmelerden ve çatışmalardan da beslenen muhtelif çelişkiler barındırmaktadır. Bu bağlamda bu çalışmada özgün olarak, Avrupa Birliği'nin yeni bütçesinin henüz taslak halinde olduğu ve onay sürecinde tartışılmaya devam edildiği de dikkate alındığında, yeni mali tasarıya ve onun asli bileșenlerine yönelik erken bir analiz ve yeri geldiğinde eleştirel bir bakış ortaya konulmaya çalışılmıştır.
\end{abstract}

Anahtar Sözcükler: Çok Yıllı Mali Çerçeve, Bütçe Öncelikleri, Brexit, Yeni Özkaynaklar Sistemi, AB Bütçe Harcamaları

\begin{abstract}
The aim of this study is to analyze the 2021-2027 Multiannual Financial Framework by taking into account the new cyclical priorities reflected on the European Union budget and the current challenges that condition these priorities. In this respect, the main texts, evaluations, reports and supplementary documents and conclusions of the official institutions -especially the European Commission-as well as the content of official data were scrutinized systematically by analyzing and interpreting them. The unique characteristics of the European Union, as a unique example of integration in terms of its structure and evolution, has been infiltrated in all its components and policies, reflected on its budget too. The European Union's budget, which is a kind of redistribution mechanism, has followed a development line intertwined with the dynamics of European integration and political priorities. In the process from the first periods of the Community to the present day, the European Union has changed and transformed by transferring the impact of global and regional developments reflected on each fiscal period to its priorities, while preserving its basic strategic discourses and policies. The current budget period (2014-2020) is inevitably shaped by the global financial crisis and the Euro Area Crisis, while the 2021-2027 budget is designed to prioritize measures to address deepening political, social and environmental crises, as well as the economic dimension. In the new financial period of the European Union, the priorities set to deal with current challenges have significantly affected the structure, size and allocation of funds in the budget. Thus, this new period, which started with the discourse of "A Modern Budget for a Union that Protects, Strengthens and Defends", was planned by putting the headings and programs in practice, in other words, efficiency in the center. However, this draft contains various contradictions that are fed by the current developments and conflicts for the Union. Within this context, originally in this study, when it is taken into consideration that the new budget of the European Union is still in draft and it is still being discussed during the approval process, it is attempted to make an early analysis and a critical view if need be, to the official text and its essential components of the new financial framework.
\end{abstract}

Keywords: Multiannual Financial Framework, Budget Priorities, Brexit, New System of Own Resources, EU Budget Expenditures

\section{Giriș}

Çok Yıllı Mali Çerçeve (ÇYMÇ), Avrupa Birliği'nin (AB) uzun vadeli bütçesidir. ÇYMÇ’ler, yedi y1llık bir plan dahilinde gerek tüm AB harcamalarına, gerekse muhtelif faaliyet alanlarına yönelik bütçesel sınırları belirlemektedir. ÇYMÇ'lerin amacı, ortak bütçe harcamalarını Birliğin siyasi öncelikleriyle uyumlu hale getirmek, bütçe disiplinini sağlamak, yıllık bütçelerin kabul süreçlerini kolaylaştırmak ve AB mali desteklerinin rotasını çizerek öngörülebilir bir yapı sunmaktır. Bu uzun vadeli finansman yaklaşımı ile Birliğin önceliklerini yansıtan tüm politika ve programlar daha etkin ve bütüncül bir nitelik kazanmaktadır (European Council, 2019). Siyasi önceliklere göre belirlenen bütçesel öncelikler, kurumlar arası müzakere ve anlaşmalar yoluyla şekillenmektedir. Avrupa Parlamentosu, Konsey ve Komisyon bir araya gelerek yeni mali döneme dair temel bütçe öncelikleri ve politika alanları üzerinde uzlaşmakta, takip eden süreçte

Makale Gecmiși / Article History

Başvuru Tarihi / Date of Application Kabul Tarihi / Acceptance Date
: 7 Ekim / October 2019

: 23 Ekim / October 2019 
ise kurumlar arası anlaşmaya uygun olarak Birliğin harcamaları için mali bir çerçeve çizilmektedir (Güvenç, 2010a: 11). ÇYMÇ, ekonomik ve siyasi bütünleşmeyi güçlendirmeye yönelik ortak politikaların finansmanı başta olmak üzere, ülkeler arasındaki gelişmişlik farkını azaltarak yakınsamayı sağlamak, büyüme, dayanışma, güvenlik ve bilgi toplumu doğrultusunda ekonomik güçlenmeyi olanaklı kılmak gibi temel hedef ve söylemleri merkeze alarak tasarlanmaktadır. Böylelikle $\mathrm{AB}$, bu hedef ve söylemleri gerçekleştirmek üzere oluşturulan ekonomik, sosyal ve kültürel politikaları doğrultusunda çiftçi, öğrenci, sivil toplum örgütü, üniversiteler, bilim insanları vb. olmak üzere onlarca ülkeden yüz binlerce yararlanıcıya ve projeye yönelik mali desteğini kapsamlı ve sistematik bir çerçevede yönetebilmektedir.

Günümüzde $\mathrm{AB}$, üretim faktörlerinin serbest dolaşımının yanı sıra ortak bir para biriminin geçerli olduğu uluslarüstü bir sisteme evrilmiştir. Ekonomik ve Parasal Birlik (EPB) kimliğini taşımasına rağmen yapısal uyum ve mali yakınsama bağlamında derin çelişkileri de bünyesinde barındıran bu -sui generis- bütünleşme pratiğinin, -sui generis- bir bütçeye sahip olması da kaçınılmaz olmuştur. AB bütçesi -her ne kadar belli fonlar ile sahaya yansıyan stratejik bir yatırım bütçesi niteliğini taşıyor olsa da- ulusal bir bütçede olduğu gibi toplumsal politikaların tüm yaşamsal aktivitelere doğrudan yansımasını sağlayan siyasi bir araç niteliğindedir. Toplumsal politikalar ise yeniden dağıtım politikalarının bir yansımasıdır. Bu noktada, Birliğin bazı kaynaklara bir nevi el koymasına (muhtelif finansman kalemleri yoluyla) ve bunların yeniden dağıtımına (harcanmasına) yönelik asli aracı bütçedir. Bir yeniden dağıtım mekanizması olarak bütçe, Birlik açısından gerek bütünleşmenin dinamikleriyle, gerekse politik öncelikleri ile iç içe geçmiş bir gelişim çizgisi izlemektedir. Bütçenin gelişimini ve dönüşümünü belirleyen asli faktörün, temel politika alanlarının evrimi doğrultusunda sahaya yansıyan kaynak yaratma ve harcama uygulamaları olduğunu söylemek yanlış olmaz (Kurtar ve Cengiz, 2019: 132). Nitekim Birlik kaynakları, ÇYMÇ’lerde belirtilen dönemsel önceliklere uygun olacak şekilde tahsis edilmektedir. $\mathrm{Bu}$ öncelikler ise ÇYMÇ'ler ile sistemli hale getirilen mali destekleri sahaya yansıtan geniş bir yelpazeye yayılmış fonlar ve programlar aracılığıla hayata geçirilmektedir.

Topluluğun ilk dönemlerinden günümüze kadar geçen süreçte $\mathrm{AB}$, temel stratejik söylem ve politikalarını korumakla birlikte, her bir mali döneme yansıyan küresel ve bölgesel gelişmelerin etkisini dönemsel önceliklerine aktarmak suretiyle değişmiş ve dönüşmüştür. Mevcut bütçe dönemi (2014-2020) kaçınılmaz olarak küresel finans krizinin ve Euro Alanı Krizi'nin gölgesinde şekillenirken, 2021-2027 bütçesi ise ekonomik boyutun yanı sıra derinleşmekte olan siyasi, sosyal, çevresel krizlerin ve Brexit sürecinin gölgesi altında tasarlanmıştır. Birliğin yeni mali döneminde, güncel zorluklarla başa çıkabilmek için belirlenen öncelikler, bütçedeki fonların yapısını, büyüklüğünü ve tahsisini de önemli oranda etkilemiştir. "Koruyan, Güçlendiren ve Savunan bir Birlik için Modern bir Bütçe” söylemiyle başlayan yeni dönem, bütçe başlıklarının ve programların uygulamada sonuç verebilmesine, diğer bir deyişle verimliliğe odaklanarak planlanmıştır. $A B$ bütçesi, geniş çaplı göç dalgalarından yeni güvenlik tehditlerine ve oradan küresel ssınmaya kadar birçok yakıcı soruna Birliğin verdiği tepkinin mali boyutunu temsil etmiştir. Böylece ortak bütçede yeni dönem öncelikleri olarak araştırma ve geliştirme, gençlik, dijital ekonomi, sınır yönetimi, güvenlik ve savunma, iklim değişikliği/krizi gibi güncel boyutlar ön plana çıkmıştır. (Kurtar ve Cengiz, 2019: 140-141)

AB'nin yeni mali yol haritasını incelemeye yönelik bu çalışma, henüz taslak halinde olan yeni ortak bütçenin ve onun asli bileşenlerinin erken ve yeri geldiğinde eleştirel bir bakışla analizini amaçlamaktadır. Bu doğrultuda, konuya ilişkin başta Avrupa Komisyonu olmak üzere resmi kurumlara ait asli metinler, değerlendirmeler, raporlar ve tamamlayıcı belge ve bağıtların yanı sıra resmi verilerin içeriği, sistematik olarak incelenmek ve yorumlanmak suretiyle analiz edilmiştir.

\section{2021-2027 Çok Yıllı Mali Çerçevesi: Güncel Zorluklar ve Öncelikler}

AB açısından 2021-2027 mali dönemine dair başlıca zorluk, gerçekleşmesi beklenen Brexit sonrası bir döneme, diğer bir deyişle 27 üyeli yeni bir bütçe sistemine uyarlanma zorunluluğu olarak ortaya çıkmaktadır. Öngörülen bu ayrılık gerçekleştiğinde $\mathrm{AB}$, ortak bütçe açısından önemli bir net katılımcısını kaybedecektir. Örneğin mevcut çok y1llı mali dönemin ilk dört yılı itibariyle Birleşik Krallık, bütçeden aldığını yaklaşık 28 Milyar Euro aşan bir katkıda bulunmuş ve bu meblağ Birleşik Krallık’ı Almanya'nın ardından bütçeye ikinci net katılımcı ülke konumuna getirmiştir. Birleşik Krallık'ın, 2021 yılından itibaren bütçeye katkı sağlamayı bırakması durumunda ortaya çıkacak olan finansal etkinin, bütçenin yaklaşık \% 7,1'ine denk düşen yıllık asgari 10-12 Milyar Euro tutarında gerçekleşmesi beklenmektedir. ${ }^{1}$ Bu finansman açı̆̆ı, net katkı sağlayan ülkeler ile bütçenin net yararlanıcısı konumundaki ülkeler arasında hâlihazırda karmaşık olan müzakereleri daha da zorlaştıran önemli bir unsurdur. Brexit sonrası belirecek olan finansman açı̆̆ı, katkı paylarında artışa gitmek ve harcamaları azaltmak arasında bir tercihte bulunulmasını veya bu olasılıkların dengeli bir bileşkesinin oluşturulmasını kaçınılmaz kılmaktadır. Katkı paylarında artışa gidilmesine yönelik bir tutum, bu kez de oluşacak yeni yükün üye ülkeler arasında nasıl pay edileceğine dair önemli bir zorluk ortaya çıkaracaktır. Brexit sonrası oluşacak olan söz konusu açığın meblağı bile başıı başına üye ülkelerin yeni dönem için belirlenen öncelik alanlarına daha fazla katkı sunma motivasyonuyla çelişecek bir sürece kapı aralamıştır. Birliğin yeni politik önceliklerinin daha çok kaynağı ve daha yakın koordinasyonu koşullandırdığı bir süreçte ve özellikle ar-ge, dijital dönüşüm, gençlik hareketliliği gibi alanlarda kayda değer artışlara yönelik uzlaşıya eğilimli bir dönemde, mevcut bütçe öncelikleri için harcamaların nasıl sürdürüleceği, bütçenin önündeki önemli bir zorluk olarak ayrıca ön plana çıkmaktadır.

\footnotetext{
${ }^{1}$ Birleşik Krallık’ın, Brexit'in ardından gümrük birliği veya ortak pazarın bir parçası olarak kalması, yeni bütçeyle olan ilişkisini daha somut bir çerçevede sürdürebilmesini sağlayabilirdi. Şu aşamada oldukça uzak bir olasılı̆̆ı temsil etse de böylesi bir senaryoda, Birleşik Krallık'tan AB yapılarına katılımı çerçevesinde gerçekleşecek sürekli bir mali katkı söz konusu olabilecektir.
} 
Bununla birlikte Birleşik Krallık’ın ortak bütçeye olan mali katkısı, buz dağının yalnızca görünen kısmıdır. Çıkış ücreti (exit fee) olarak adlandırılan ödemeler de dahil olmak üzere söz konusu nominal tutarlar, gerek Birlik gerekse Birleşik Krallık milli gelirinin yanında oldukça düşüktür. Brexit'te asıl önemli boyut, gelecekteki ticaret, hizmetler ve göç ortaklıkları gibi ilişkilerin ekonomik büyüme ve dolayısıyla doğrudan bütçe gelirleri üzerindeki reel etkisidir. Benzer şekilde güvenlik ve savunma, havacılık, vizesiz seyahat, nükleer güvenlik ve gıda güvenliği gibi işbirliği alanlarındaki değişimin ilk planda iktisadi görünmeyen etkilerinin önemli ve dolaylı yansımaları olacaktır. Ayrılık sonrası oluşacak ticari sapmanın etkisiyle ortaya çıkacak olan maliyet artışları, özellikle zirai gıda endüstrisi ve balıkçılık sektörleri için yüksek olacaktır. Birleşik Krallık'la ticaret yapan KOBİ'ler başta olmak üzere ticari aktörler, bütçe dahilinde daha kapsamlı ek desteklere gereksinim duyacaktır (European Commission, 2019a).

Yeni dönem bütçe müzakerelerinde, halihazırda \%1,03 olan Birlik GSMH payının \%1,14'e yükseltilmesi ve böylelikle Birlik ekonomisinin büyüklüğüne kıyasla mütevazı fakat önemli etkileri olan bir artışın sağlanması öngörülmüştür. $\mathrm{Bu}$ noktada kaçınılmaz olarak ortak bütçeye yönelik üye ülkeler arası çelişkileri besleyen yapısal eleştiriler söz konusu olmaktadır. Örneğin, Avusturya, Hollanda, Danimarka ve İsveç gibi daha küçük bir bütçe yanlısı varsıl üyelerin, milli gelir payında artış önerisine karşı durduğu ve Brexit sonrası bütçe miktarının azaltılmasını ve bunun yerine verimlilik artışına daha çok odaklanılmasını savunduğu görülmektedir. Benzer bir çelişki de bazı üye ülkelerin Brüksel'e mali yetki devretme konusundaki gönülsüz tutumlarına karşın, Komisyon'un çevre vergileri vb. yollarla öz kaynaklar için yeni gelirler yaratmayı planlamasında yatmaktadır. Bütçenin harcama boyutunda ise yeni önceliklere ilişkin harcama taahhütlerinin basitleştirilmesi ve reformunun yanı sıra en büyük iki temel harcama alanı olan OTP ve Uyum Fonları'na ayrılan kaynakların azaltılması kararlaştırılmıştır. Yeni bütçenin finansmanına yönelik bu eğilim de örneğin İrlanda ve Polonya gibi bu kadim fonlardan en net yararlanan ülkeleri olumsuz yönde etkileyecek ve üyeler arasında önemli bir ihtilaf konusuna daha kapı aralayacak bir etki yaratmaktadır.

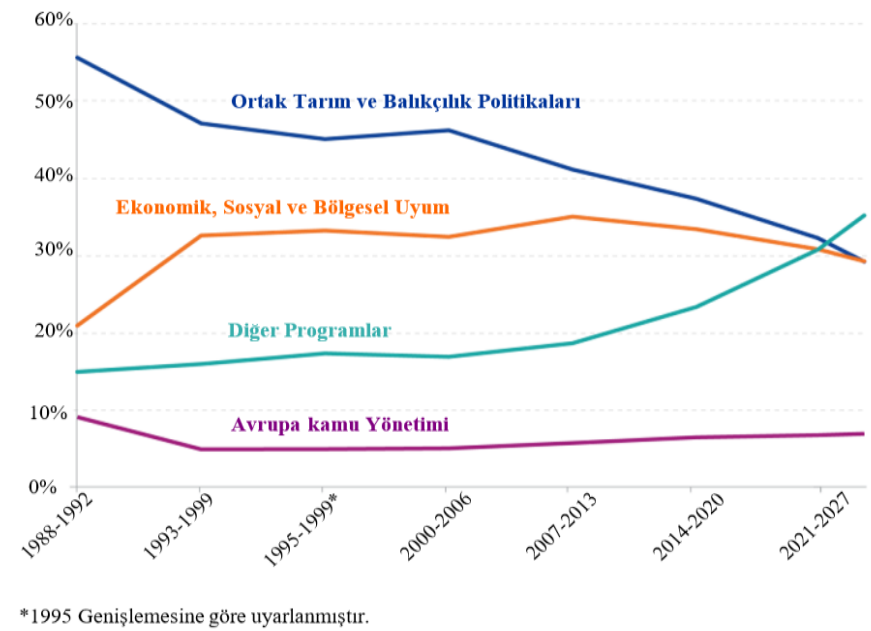

Şekil 1. AB Bütçesinde Harcama Alanlarının Evrimi

Kaynak: European Commission, $2018 b$.

Yeni dönemde OTP'ye ilişkin en önemli çelişki ise, bütçedeki indirime rağmen çiftçi desteklerinin ve çevre fonlarının yeterli ve doğru kanalize edilebilmesindeki belirsizlik olarak ön plana çıkmaktadır. Bu noktadaki belli harcama süreçlerinde ulusal hükümetlere daha fazla yetki tanınmasına yönelik eğilimlerin, ister istemez çevresel koşulluluk boyutunun suiistimali ve üye ülkeler arasında bir takım rekabetçi faktörleri tetikleme olasılığını barındırdığı söylenebilir. Bu nedenle bu olasılık, Parlamento'nun ve çevreci aktörlerin tepkisini çekmekte ve özellikle çevresel koruma tedbirlerinin Komisyon ile üye ülkeler arasındaki müzakerelere indirgenme olasılığı, Parlamento'nun bu alandaki etkisini ve denetim yetkisini aşındıracak bir nitelik arz etmektedir. Dolasıyla ister kaçınılmaz bir küresel gündem, isterse bölgesel bir mali zorluk olarak değerlendirilsin, çevre ve iklim krizi, Birliğin ortak politika ve önceliklerinin ağırlık merkezine yaklaşmaya devam etmektedir. Nitekim konuya bütçe açısından bakıldığında, yeni dönemde iklim hedeflerine yönelik Birlik katkısının, harcamaların minimum \%25'ine ve dönem bitmeden \%30'una yayılması gerektiğinin, başta Avrupa Parlamentosu olmak üzere Birliğin çok sayıda farklı kurum ve aktörlerince savunulduğu dikkati çekmektedir.

2021-2027 mali çerçevesinde yeni bir temel harcama başlığında ele alınacak olan göç ve sınır yönetimi sorunu, ekonomik ve sosyal boyutlu derin bir krizi temsil eden böylesi bir alanda ciddi bir fon artışını kaçınılmaz kılmıştır. Bölgesel olduğu kadar küresel anlamda da başlıca güncel zorluk olan göç krizi, ekonomik bunalımla sarsılan Avrupa ülkelerinde işsizliğin artış eğilimini desteklerken, köktenci hareketlerin etkinliği artmış ve çatışmalı bölgelerden Avrupa'ya uyuşturucu ticareti başta olmak üzere yasadışı transferler yoğunlaşmıştır. Bu konuda alınması gereken kapsamlı önlemler, bütçe açısından öncelikli ve zorlu bir alan açmakta, bununla birlikte Birliğin gerçek manada ortaklaşmış bir göç politikasından yoksun oluşu, alınan önlemlerin etki kapasitesini sınırlama riski barındırmaktadır. 


\section{Yeni Dönemde Gelirler ve Harcamalar: Reformların Ana Hatları}

AB bütçesi, Birliğin temsil ettiği ekonomik yapıya kıyasla küçük fakat bir o kadar da ihtilaflı bir bütçedir (Benedetto ve Milio, 2012: 1). Bunun yanı sıra yapısı ve bileşenleri itibariyle bir uluslararası organizasyondan ziyade ulusal bir bütçe ile kıyaslanabilir niteliktedir. Bu nitelik, bütçenin nominal büyüklüğü, gelirlerin toplanmasındaki kısmi mali otonomi ve Parlamento'nun bütçenin oluşturulma ve nihai süreçlerindeki yetkileri dikkate alındığında daha iyi anlaşılmaktadır. Birlik bütçesi de gelir ve harcama bölümleri ile ikiye ayrılmış ve Antlaşma hükümleri uyarınca dengeli olması koşullandırılmıştır. Bunun anlamı, her bir Euro'luk harcama karşılığında ona denk bir gelir kaleminin olması ve ortak bütçenin finansmanı için -ulusal hükümetlerin maliye bakanlıklarının başvurduğu gibi- herhangi bir ödünç yolunun kullanılmamasıdır (İKV, 2004: 6-7).

2014-2020 mali döneminin sonuna yaklaşırken, ortak bütçenin zayıf ve aksayan yönleri daha da belirginleşmiştir. Nitekim yeni taslakta, bütçenin hala çok katı bir yapısallık arz ettiği, yeterli esnekliğe sahip olmadığı ve Birliğin hızla değişen küresel etkilere yeterince hızlı ve etkin tepkiler verebilmesine engel olduğu ifade edilmiştir. Karmaşık ve birbirinden farklı finansman kuralları, bütçenin ilgili fonlarına ve fiili sonuçlara erişmeyi zorlaştırdığı gibi, bu fonlar, bütçenin içinde veya dışında çok sayıda program ve araca dağılmış durumdadır. Bunun üstesinden gelebilmek için öncelikle bütçenin en büyük iki harcama bloğu ve en ihtilaflı alanları olan OTP'nin ve Uyum Politikası'nın daha modern ve daha basit hale getirilmesi planlanmıştır. Ayrıca, yeni bütçe döneminin düsturu olarak belirlenen "koruyan, güçlendiren ve savunan bir Birlik" için modern bir bütçenin ve yeni önceliklerin bir söylem olmaktan çıkıp eyleme dökülebilmesi için yeni ve özel araçların gündeme getirilmesi kaçınılmaz olmuştur.

Avrupa Komisyonu'nun kapsamlı harcama incelemesi raporu ve yeni bütçe taslağı birlikte incelendiğinde, öncelikle Avrupa artı değerine daha güçlü bir şekilde odaklanma vurgusu dikkati çekmektedir. Bunun anlamı, kaynak havuzunun, üye ülkelerin tek başlarına hareket ettiklerinde ulaşamadıkları sonuçlara ulaşabilecek bir potansiyel barındırmasıdır (European Commission, 2018a). Bu noktadaki başlıca örnekler arasında Avrupa'daki en iyi araştırmacıları bir araya getiren en gelişmiş araştırma projeleri veya ortak pazar ve dijital ekonominin sunduğu firsatlardan tam olarak yararlanabilmeleri için gençleri ve küçük işletmeleri güçlendirme işlevi ön plana çıkmaktadır. İkinci olarak daha modernleştirilmiş ve şeffaf bir bütçe vurgusu ön plana çıkmaktadır. Komisyon bu noktada daha tutarlı, odaklı ve şeffaf bir yapı önerisinde bulunmakta ve yeni bütçe yapısının daha net ve önceliklerle daha tutarlı olacağını ileri sürmektedir. Parçalı bir yapı arz eden fon kaynaklarının bir araya getirilip, yeni entegre programlara dahil edilmesi ve bu yolla finansal araçların kullanımının önemli ölçüde kolaylaştırılarak program sayısının üçte birden daha fazla bir oranda azaltılacak olması yeni bütçeye yönelik en göze çarpan reform olarak dikkati çekmektedir. Bunları destekleyecek bir diğer yenilik ise yararlanıcılar için daha az bürokrasi olarak ifade edilmiştir. Böylelikle Komisyon, işleyişin tek bir kural kitabının düzenlemeleri çerçevesinde sade ve tutarlı hale getirilmesi gerekliliğinin altını çizmiştir. Bunun, yararlanıcılar ve idari makamlar için idari yükü büyük ölçüde azaltmakla kalmayacak, aynı zamanda programlara katılımı kolaylaştıracak, uygulama süreçlerini ve farklı program ve araçların senkronizasyonunu hızlandıracak bir yenilik vurgusunu içerdiği anlaşılmaktadır.

Daha esnek ve faal bir bütçe yaklaşımıyla, programlar bünyesindeki ve arasındaki esnekliği artırmak yoluyla kriz yönetimi araçlarını güçlendirmek ve özellikle güvenlik ve göç gibi konularda beliren ani ve acil sorunlara doğru ve zamanlı tepkiyi verebilmek için yeni bir Birlik Rezervi’nin de oluşturulması gerekliliği masaya yatırılmıştır. Bu doğrultuda, programlar arasında, başlıklar ve yıllar arasında ve özel araçların kapsamı dâhilinde daha işlevsel ve esnek bir yapı hedeflenmiştir. Buna benzer şekilde bir diğer yenilik vurgusu da işleyen bir bütçe üzerinde şekillenmektedir. Bunun anlamı, bütçenin, ancak sahada somut sonuçlar verdiği takdirde bir başarı hikâyesi olarak değerlendirilebileceğidir. Komisyon, daha net hedefler belirlemek ve daha yüksek kaliteli performans göstergelerinden daha azına odaklanmak dâhil olmak üzere, tüm programlarda performans üzerindeki odağı güçlendirmeyi teklif etmektedir. Bu yolla sonuçların izlenmesinin, ölçülmesinin ve gerektiğinde dönüştürülmesinin kolaylaşacağı öngörülmüştür (European Commission, 2018b). Yeni mali dönemde, programlar içinde esneklik sağlamak için dâhili rezervler önerilirken, buna ek olarak, aynı başlık içerisindeki bir programdan diğerine aktarılabilecek miktarın \%10'dan \%15'e çıkarılması planlanmıştır. Ayrıca, farklı finansal destek türlerini harmanlama, farklı yönetim modları arasında hareket etme, orta vadede fonu yeniden programlama ve ayrıca gelişmelere uyum sağlamak için ulusal dağıtımlara belirli revizyonlar teklif edilmiştir. Bunların yanı sıra, Acil Yardım Rezervi, Avrupa Birliği Dayanışma Fonu ve Avrupa Küreselleşme Uyum Fonu gibi özel araçların kapsamı gözden geçirilmiştir. Bu fonlar, belirlenen tavan değerlerin üzerinde bulunacak ilave finansal araçların varlığına izin vermektedir. Komisyon, gerekli hallerde, örneğin AB içindeki acil durumlar için Acil Yardım Rezervi'nin etkinleştirilmesine izin vererek, araçların kapsamını genişletmeyi ve ayrıca bu araçları harekete geçirme prosedürlerini düzenlemeyi ve esneklik aracının boyutunu her sene için 1 Milyar Euro'ya çıkarmayı teklif etmiştir (Kurtar ve Cengiz, 2019: 79-80). Sonuç olarak bütçenin yapısına ve etkinliğine ilişkin bütün bu düzenlemelerin, aşağida incelenecek olan yeni öz kaynaklar sisteminin ve harcama önceliklerinin sorunsuz işleyebilmesi adına ve önceki mali dönemlerin aksayan yönleri dikkate alınmak suretiyle tasarlandığı anlaşılmaktadır.

\subsection{Bütçenin Finansmanı: Yeni Öz, Kaynaklar Sistemi}

$\mathrm{AB}$ bütçesi, üye ülkelerden gelen milli gelir katkıları, Birlik dışından gelen ürünlere uygulanan ithalat vergileri ve işletmelerin Birlik kurallarına uymadığı durumlarda uygulanan para cezaları gibi kaynaklar ile finanse edilmektedir. Ortak bütçede geleneksel öz kaynaklar diye bilinen gelirler, Topluluğun ilk dönemlerinden bu yana uluslarüstü gelir kaynağ 
niteliğiyle bütünleşmenin öz kaynaklarını temsil etmekte ve Birlik dışından yapılan ithalat ve şeker vergileri üzerindeki gümrük vergilerini kapsamaktadır. KDV katkısına dayalı öz kaynak ise AB düzeyinde geniş çapta uyumlaştırılan ilk vergi olarak Birliğin ikinci türdeki öz kaynağını oluşturmaktadır. İlk olarak 21 Nisan 1970 tarih ve 70/243 sayılı Konsey Kararı ile Topluluğa mali özerklik sağlanırken, ortak bütçenin de tamamen kendi kaynaklarından finanse edilmesi sağlamıştı. $\mathrm{Bu}$, üye ülkelerin mali katkılarının Birliğin öz kaynaklar sistemi ile ikame edilmesi ve KDV katkısına dayalı öz kaynağın getirilmesiyle gerçekleştirilmişti. Gayri Safi Milli Hâsıla (GSMH) katkısına dayalı öz kaynak ise asıl itibariyle bir "ek kaynak" olarak ifade edilmekle birlikte, geleneksel öz kaynaklar ve KDV katkısına dayalı öz kaynaklar tarafından finanse edilen tutarın üzerindeki harcamaları karşılamak için gereken gelirleri sağlamaktadır. GSMH katkısının asli işlevi, Birliğin ortak bütçesinin her zaman dengede olmasını sağlamaktır. Nitekim "çağrı oranları" olarak ifade edilen katkı düzeyleri, öz kaynaklar tarafından karşılanmayan bütçelenmiş harcamaları finanse etmek için gereken ek gelire göre belirlenmekte ve böylelikle her bir üye ülkenin milli gelirine uygulanmaktadır. Dolayısıyla bu karşılama mekanizmasına göre üye ülkelerin milli gelirine uygulanacak oranlar, bir mali yıldan diğerine farklılık göstermektedir. GSMH katkıs1 günümüzde genel bütçe gelirlerinin üçte ikiden fazlasını kapsayan en büyük gelir kaynağını temsil etmektedir (European Commission, 2019b).

Üye ülkelerin Birlik bütçesine katkıları, nispi ekonomik güçleri doğrultusunda milli gelir baz alınarak hesaplanırken, bu durum ortak bütçenin gelir tarafındaki dayanışma ve adalet boyutunun dengeli biçimde sürdürülebilmesinin bir unsuru olmuştur. Bu unsur, her ne kadar nesnel ekonomik kriterlere dayalı bir finansman yaklaşımıyla belli bir sisteme oturtulmuş olsa da, geçmişte Birleşik Krallık başta olmak üzere bazı üye ülkelerin diğerlerine kıyasla Birlik bütçesine reel anlamda daha fazla katkıda bulunduklarına dair itirazlara yol açmaktaydı. Bu itirazlar ise bir indirim mekanizması olarak işleyen ve aşırı görünen finansal katkıların düzeltilmesi (correction) için bir takım önlemlerin uygulamaya konulmasına kapı aralamıştır.

UK Rebate diye bilinen Birleşik Krallık bütçe iadesi, Birleşik Krallık’ın katkısı ile bütçeden geri aldıkları arasındaki farkın yaklaşı üçte ikisini tazmin eden bir mekanizma sunmaktaydı. Bu iadenin maliyeti, Birliğin milli gelirine katkıda bulundukları payla orantılı olarak üye ülkeler arasında bölünmüştü. Bununla birlikte, bu mekanizma 2002 y1lından itibaren Almanya, Hollanda, Avusturya ve İsveç için normal finansman paylarının \%25'i ile sınırlı tutulmuştu. Örneğin 2014-2020 dönemi için Danimarka, Hollanda ve İsveç, yıllık milli gelir katkısındaki brüt indirimlerden 2011 fiyatlarıyla olmak üzere sırasıyla 130 Milyon Euro, 695 Milyon Euro ve 185 Milyon Euro tutarında faydalanmaktadır. Avusturya ise yıllık milli gelir katkısındaki brüt indirimden 2016 yılına kadar yararlanmıştır. Benzer bir indirim mekanizması da KDV katkıları açısından söz konusudur. Örneğin yine 2014-2020 döneminde Almanya, Hollanda ve İsveç gibi ülkeler için, normalde \%0,30 olan KDV çağrı oranları \%0,15'e sabitlenmiştir (European Council, 2014; European Parliament, 2018). Öz kaynaklar sisteminde geçmişten günümüze süregelen en temel sorun, UK Rebate ile başlayıp diğer istisnai düzenlemeler ile devam eden bu karmaşık indirim mekanizmaları olmuştur. Bu mekanizmalar, bütçe sisteminin şeffaf yapısına zarar vermekte ve finansman koşullarına dair sistematiği daha karmaşık bir hale getirmektedir. Özellikle UK Rebate mekanizması, katkı kapasitesi ilkesinin (ability to pay principle) en önemli istisnasını oluşturmakta, sistemin eşitlik prensibine olumsuz etki etmekte ve Birleşik Krallık dışındaki üye ülkelerin bütçeye normalde olması gerekenden daha fazla ödeme yapmasına yol açtığı gibi, ardıl istisnai mekanizmaları da (rebates on the rebate) teşvik etmektedir. Örneğin, yukarıda da değinildiği gibi Almanya, Hollanda, Avusturya ve İsveç gibi bütçeye en çok fon aktaran üye ülkeler, Birleşik Krallık indiriminin finansmanına diğer üye ülkelerden daha farklı bir şekilde ve farklı indirim düzenlemeleri ile katılmaktadır (Güvenç, 2010b: 529).

2021-2027 ÇYMÇ döneminden önce gerçekleşmesi öngörülen Brexit'in, bütçedeki iade mekanizmalarının da ortadan kaldırılması için önemli bir firsat sunduğu açıktır (European Parliament, 2018: 5). Birlik mevzuatında yer tutan istisnai uygulamaların terk edilebilmesi için Birleşik Krallık'ın ayrılmasından da öte, gerek ayrılma şartlarının belirginleşmiş olması, gerekse tüm üye ülkelerin fikir birliği ve onayının sağlanması gerekmektedir (Keep, 2019: 9). Bu koşullarda, gerek KDV katkılarına yönelik çağrı oranlarının düşürülmesiyle ilgili iadeler ve gerekse milli gelir katkı paylarındaki toptan indirim mekanizması, 2020 sonunda otomatik olarak sona erebilecektir. Bu sürecin, sistemi basitleştirmek ve reforme etmek yoluyla Birlik politikaları ve öncelikleriyle uyumu güçlendirmek için bir fırsat sağlayacağından hareketle yeni mali çerçevede, bütçenin finansmanına yönelik tüm istisnai mekanizmaların adil ve dengeli bir bütçe doğrultusunda ortadan kaldırılması planlanmıştır (European Commission, 2018b). Tüm iadelerin kaldırılması ve gümrük gelirleri için tahsilat maliyetlerinin azaltılmasıyla birlikte yeni ÇYMÇ’nin daha adil bir yapıya kavuşması hedeflenmiştir. Bununla birlikte, iadelerin kaldırılmasıyla yeni ÇYMÇ'nin bazı üye ülkeler adına mevcut durumlarına kıyasla önemli bir katkı artışı sağlayacağı öngörülmüş, böylelikle yeni dönemde üye ülkelerin yapacağı katkılarda oluşacak önemli ve ani bir artışın önünü alabilmek için mevcut iadelerinin aşamalı olarak ortadan kaldırılması gündeme gelmiştir. Bu kademeli plan doğrultusunda, bütçenin gelir tarafındaki tüm düzeltmeler şeffaf toplu ödemelere (lump sum corrections) dönüştürülürken; bu toplu miktarların ise -milli gelirin yüzdesiyle ölçülen ulusal düzeydeki katkılar geri ödemeden yararlanamayan diğer üye ülkelerle karşılaştırılabilir bir düzeye erişene kadar- kademeli olarak beş yıl kadar sürdürülmesi planlanmıştır.

Böylece 2021-2027 dönemi için ilave katkıların ve tasarrufların bir araya getirilmesiyle belirlenen taahhütler doğrultusunda AB-27 GSMH'sinin \%1,1'ine karşılık gelen 1.279 Milyar Euro'luk bir mali çerçevenin tasarlandığı görülmektedir. Yeni ÇYMÇ, Avrupa Kalkınma Fonu'nun (AKF) da mali çerçeveye dâhil edilmesi sonrası reel anlamda mevcut dönemin ve daha önceki çok yıllı dönemlerin büyüklüğüyle Şekil 2'deki gibi karşılaştırılabilir. Bu seviyedeki taahhütler, mevcut ve gelecekteki harcama programlarını 2027 yılına kadar uygulamak için AB-27 GSMH'sinin 
\%1,08'ine karş1lık gelen ödemelerde 1.246 Milyar Euro’ya tekabül etmektedir. Yürürlükteki öz kaynaklar tavan değerine uyum sağlamak adına yeni ÇYMÇ’nin ilk iki yılı için Komisyon, uyum politikası ve kırsal kalkınma programları için ön finansman oranlarının azaltılmasını teklif etmiştir (Kurtar ve Cengiz, 2019: 50).

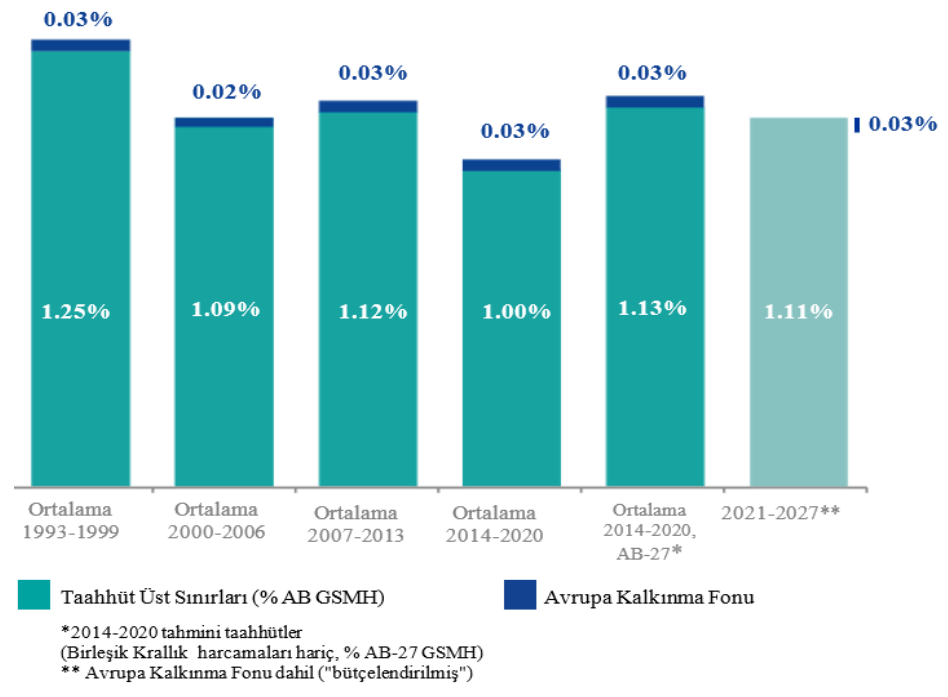

Şekil 2. AB Bütçesinin Büyüklüğü (\% GSMH)

Kaynak: European Commission, $2018 b$.

GSMH katkılarına yönelik tasarlanmış bu yeniliklerin yanı sıra, bütçenin siyasi önceliklere katkısını en üst düzeye çıkarabilmek ve mevcut öz kaynaklar sistemini modernize etmek, basitleştirmek ve gelir kaynaklarını çeşitlendirmek amacıyla 2021-2027 döneminde, Birlik dâhilinde bir nihai KDV sisteminin oluşturulması ve öz kaynağa dayalı mevcut KDV katkısını basitleştirilmiş bir yapıyla reforme edilmesi planlanmıştır (European Commission, 2017a). Bu gelir bileşenlerinin yanı sıra, yeni bir öz kaynaklar sepeti getirilerek bütçenin finansmanı ile Birliğin politikaları arasındaki bağlantının güçlendirilmesi hedeflenmektedir.

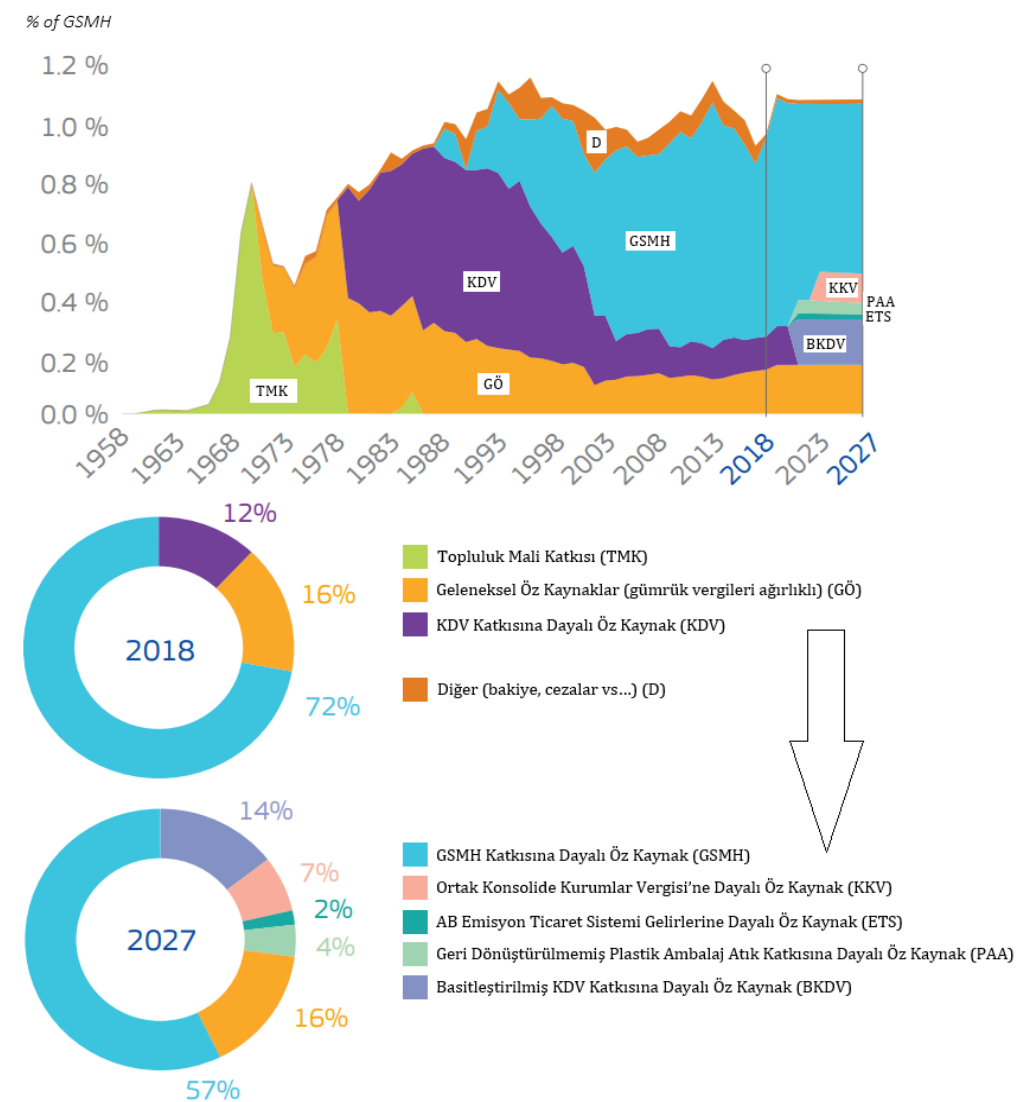




\section{Şekil 3. AB Bütçesinde Gelir Kaynaklarının Evrimi}

\section{Kaynak: European Commission, 2018 b.}

Bu sepet, Şekil 3'te görüldüğü gibi yeni kalemlerden elde edilen gelir paylarını sisteme dahil etmektedir. Bunlara bakıldığında sırasıyla; i) Avrupa Emisyon Ticaret Sistemi, sera gazı emisyon maliyetini etkin bir şekilde azaltmak için kilit bir araçtır ve ortak pazarın işleyişi ile dolaysız bağa sahiptir. Komisyon, hâlihazırda sistemde bulunan düzeltme mekanizmalarını korurken, Emisyon Ticaret Sistemi gelirlerinin \%20'sini AB bütçesine tahsis etmeyi teklif etmiştir. ii) Yeniden başlatılan Ortak Konsolide Kurumlar Vergisi'nin gerekli mevzuat kabul edildikten sonra aşamalı hale getirilmesi ve böylelikle bütçe finansmanının ortak pazarda faaliyet gösteren şirketlerin faydalandıklarıyla doğrudan ilişkilendirilmesi planlanmıştır. iii) Geri dönüştürülmemiş plastik ambalaj atık miktarı üzerinden hesaplanan ulusal katkıların ise üye ülkelerin ambalaj atıklarını azaltma ve Avrupa'nın plastik stratejisini uygulayarak üretim, kullanım ve imha sürecine ikame olarak dönüşümü ve yeniden dönüşümü esas alan döngüsel bir ekonomiye geçişi tetikleme yönünde bir teşvik yaratması hedeflenmektedir (European Commission, 2018b). Bu tekliflerine dayanarak yeni öz kaynakların, toplam bütçe gelirinin yaklaşık \%12'sine karşılık gelen yıllık ortalama 22 Milyar Euro katkıda bulunabileceği ifade edilmektedir. Yeni öz kaynakların, bütçedeki yeni önceliklerin finansmanına katkıda bulunması ve dolayısıyla milli gelire dayalı katkıların buna uygun şekilde azaltılmasını sağlaması planlanmıştır. Bunun, gerçekleştiği takdirde, Birliğin uluslarüstü yapısının güçlenmesine ve demokratikleşmesine olumlu etki edeceği açıktır. ${ }^{2}$

Tablo 1. AB Bütçesi Finansman Yapısının Tahmini Gelişimi

\begin{tabular}{|l|r|r|r|r|}
\hline & \multicolumn{2}{|c|}{$\mathbf{2 0 1 8 ~ B u ̈ t c ̧ e s i ~}$} & \multicolumn{2}{|c|}{$\mathbf{2 0 2 1 - 2 0 2 7 ~ T a h m i n i ~ O r t a l a m a}$} \\
\cline { 2 - 5 } & Milyar $€$ & Topl. gelire oranı (\%) & Milyar $€$ & Topl. gelire oranı(\%) \\
\hline Geleneksel Öz Kaynaklar & 23 & $15,8 \%$ & 26 & $15 \%$ \\
\hline Mevcut Ulusal Katkılar & 120 & $82,9 \%$ & 128 & $72 \%$ \\
\hline - (Reform sonrasl) KDV bazlı öz kaynak & 17 & $11,9 \%$ & 25 & $14 \%$ \\
\hline - GSMH bazlı öz kaynak & 103 & $71,0 \%$ & 103 & $58 \%$ \\
\hline Yeni Öz Kaynaklar & - & & 22 & $12 \%$ \\
\hline - Ortak Konsolide Kurumlar Vergisi & - & - & 12 & $6 \%$ \\
\hline - AB Emisyon Ticaret Sistemi & - & - & 3 & $2 \%$ \\
\hline - Plastik Ambalaj Atık & - & - & 7 & $4 \%$ \\
\hline Toplam Öz Kaynaklar & 143 & 2 & 176 & $99 \%$ \\
\hline Öz Kaynaklar Dişı Gelirler & 2 & $1,3 \%$ & 2 & $1 \%$ \\
\hline Toplam Gelir & 145 & $100,0 \%$ & 178 & $100 \%$ \\
\hline
\end{tabular}

* 2021-2027 dönemi ortalama tutarlar, öz kaynaklar sisteme yönelik uygulama tedbirlerini belirleyen, Konsey Tüzüğü için Komisyon Teklifinde belirtilen geçerli çağrı oranlarına dayanmaktadır (European Commission, 2018f, Madde 1). Kaynak: European Commission, 2018e: 9.

Yeni mali dönemde Birlik bütçesinin finansman yapısının tahmini gelişimini ortaya koyan Tablo 1'de de görüldüğü gibi, öz kaynaklar sisteminde gerçekleştirilecek reformların, bütçenin genel büyüklüğüne yönelik olmaktan ziyade bütçenin finansman biçimini değiştirmekle ilgili olduğu anlaşılmaktadır. Özellikle, gelir kaynaklarının çeşitlendirilmesi yoluyla bütçenin direncinin artırılabileceği öngörülmüştür. Bütçenin ulusal olarak tahsis edilen programlardan yeni önceliklere doğru kademeli olarak yeniden dengelenmesi ile bir arada düşünüldüğünde bunun, yeni bütçe taslağında sıkça sözü edilen Avrupa katma değerine daha çok odaklanmayı sağlaması ve bütçenin her iki tarafının Birliğin politik önceliklerine katkıda bulunmasına yardımcı olması beklenmektedir. Bunun yanı sıra AKF'nin Birlik bütçesine entegrasyonuna, öz kaynaklar tavan değerlerindeki artışın eşlik etmesi gerektiği, aynı zamanda Birliğin her koşul altında, ekonomik gerileme zamanlarında bile, mali yükümlülüklerini yerine getirebilmesini sağlamak için ödemeler ve öz kaynakların tavan değerleri arasında yeterli bir marjın bulunması gerektiği, yeni taslakta altı çizilen diğer bir husus olarak dikkati çekmektedir. Bu doğrultuda, ödemeler ve taahhütler için öz kaynak tavan değerlerinin AB-27 GSMH'sinin sırasıyla \%1,29 ve \%1,35'ine yükseltilmesinin teklif edildiği görülmektedir (Kurtar ve Cengiz, 2019: 53).

\subsection{Bütçe Harcamaları: Yeni Öncelikler ve Başlıklar}

AB bütçesinin kendine özgü finansmanı yoluyla elde edilen kaynaklar, mali çerçevede belirtilen siyasi önceliklere uygun olacak şekilde harcama başlıklarına tahsis edilmektedir. Birliğin genel harcama başlıkları belirlenirken, söz konusu başlıklar, ÇYMÇ’de belirtilen taahhhütler ile sınırlandırılmaktadır. Bütçe harcamalarının bir kısmı, Birliğin ortak politikalarının finansmanı için Komisyon aracılığıyla gerçekleştirilmektedir. Bu harcamalar için program ve fonlardan

\footnotetext{
${ }^{2}$ Avrupa Parlamentosu, bir yandan uluslarüstü yapıyı temsil ederken, öte yandan milli gelir paylarında artışı destekler bir pozisyondadır. Her ne kadar çelişkili bir yaklaşım gibi görünse de bu; hâlihazırda ortak bütçenin oldukça mütevazı ve fakat fonksiyonel bir yapı arz ettiği dikkate alındığında, ister uluslarüstü niteliğiyle öz kaynaklar olsun, ister uluslararası niteliği ön plana çıkan GSMH katkıları olsun, bütçenin finansmanındaki niceliksel artışlar, nihayetinde bütünleşmenin ekonomik boyutunu güçlendiren bir etki doğurmaktadır.
} 
yapılacak ödenek tahsisleri ise proje temelinde gerçekleşmektedir (Bilici, 2005: 82). Söz konusu projelere hibe aktarımı, programlara ve fonlara bütçeden aktarılan paylarla sağlanmaktadır. Programlara ve fonlara ödenek tahsisi ise, ÇYMÇ’deki harcama başlıklarına göre yapılmaktadır. Tablo 2'de de görüldüğü gibi yeni dönemde, yani 2021-2027 ÇYMÇ'sinde yer alan başlıklar şunlardır: Ortak Pazar, İnovasyon ve Dijitalleşme, Uyum ve Değerler, Doğal Kaynaklar ve Çevre, Göç ve Sınır Yönetimi, Güvenlik ve Savunma, Komşular ve Dünya, Avrupa Kamu Yönetimi.

Tablo 2. 2014-2020 ve 2021-2027 ÇYMÇ Dönemleri Harcama Başlıkları ve Payları

\begin{tabular}{|l|r|lc|r|}
\hline \multicolumn{1}{|c|}{ 2014-2020 ÇYMÇ } & \% & \multicolumn{1}{|c|}{$\mathbf{2 0 2 1 - 2 0 2 7 ~ C ̧ Y M C ̧}$} & $\%$ \\
\hline 1. Akıllı ve Kapsayıcı Büyüme & 47.2 & 1. Ortak Pazar, Inovasyon ve Dijitalleşme & 14.7 \\
la. Büyüme ve İstihdam için Rekabet Edebilirlik & 13 & 2. Uyum ve Değerler & 34.5 \\
1b. Ekonomik, Sosyal ve Bölgesel Uyum & 34.2 & 3. Doğal Kaynaklar ve Çevre & 29.7 \\
2. Sürdürülebilir Büyüme: Doğal Kaynaklar & 38.6 & 4. Göç ve Sinır Yönetimi & 2.7 \\
3. Güvenlik ve Vatandaşlık & 1.6 & 5. Güvenlik ve Savunma & 2.1 \\
4. Küresel Avrupa & 6.1 & 6. Komşular ve Dünya & 9.6 \\
5. İdari harcamalar & 6.4 & 7. Avrupa Kamu Yönetimi & 6.7 \\
\hline
\end{tabular}

Kaynak: European Commission, 2012; European Commission, $2018 \mathrm{~b}$.

Şekil 4'ten de anlaşılacağı gibi yeni ÇYMÇ, ortak ve temel politika alanlarının yanı sıra güncel gereksinimlere koşut olarak belirlenen yeni önceliklere göre tasarlanmıştır. Yeni bütçede de programlar, resmi bütçe yapısında başlıklara karşılık gelen tematik harcama önceliklerinin altında sıralanmıştır. Dolayısıyla bu programlar, yıllık bütçenin başlıklarına yansıyan politika kümelerinde gruplandırılmış olmaktadır. Bu da söz konusu programların hangi politika hedeflerine ve nasıl katkıda bulunacakları konusunda netlik sağlayan bir sistem sunmaktadır. 


\begin{tabular}{|c|c|}
\hline & $\begin{array}{l}\text { I. ORTAK PAZAR, INOVASYON } \\
\& \text { DİITALLEȘME }\end{array}$ \\
\hline \multicolumn{2}{|c|}{ 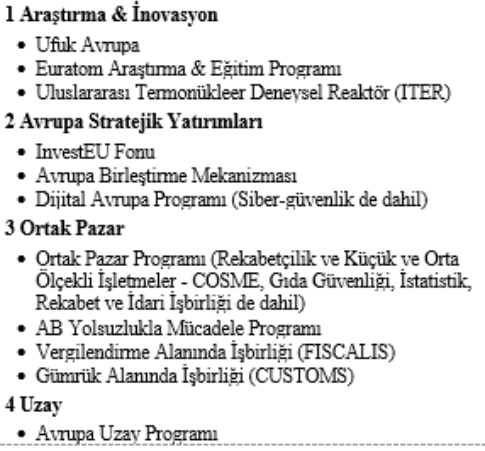 } \\
\hline & II. UYUM \& DEĞERLER \\
\hline $\begin{array}{l}5 \text { Bölgesel } \\
\text { - Avrupa } \\
\text { - Uvum } \\
\text { - Kubrisl } \\
6 \text { Ekonom } \\
\text { - Reform } \\
\text { Yakms } \\
\text { - Euro'y } \\
7 \text { İnsanlar } \\
\text { - Avrupe } \\
\text { - Eağllik } \\
\text { Erasmu } \\
\text { - Avrupe } \\
\text { - Adalet } \\
\text { Yaratic }\end{array}$ & $\begin{array}{l}\text { llanma \& Uyum } \\
\text { blgesel Kalkanma Fonu } \\
\text { un } \\
\text { irk Toplumunun Desteklenmesi } \\
\text { \& Parasal Birlik } \\
\text { estek Programı (Reform Teslimat Aracı ve } \\
\text { a Mekanizması da dahil) } \\
\text { ahteciliğe Karş1 Koruma } \\
\text { aturm, Sosyal Uyum \& Değerler } \\
\text { syal Fonu + (Göçmenlerin Entegrasyonu ve } \\
\text { gramı da dahil) } \\
\text { ayamışma Mekanizması } \\
\text { allar \& Değerler } \\
\text { vnupa (MEDIA programı da dahil) }\end{array}$ \\
\hline$(2+2)$ & $\begin{array}{l}\text { III. DOĞAL KAYNAKLAR \& } \\
\text { ÇEVRE }\end{array}$ \\
\hline $\begin{array}{l}8 \text { Tarum \& } \\
\text { - Avrupe } \\
\text { - Krrsal } \\
\text { - Avrupe } \\
9 \text { Çevre \& } \\
\text { - Ceure }\end{array}$ & $\begin{array}{l}\text { enizcilik Politikası } \\
\text { anmsal Garanti Fonu } \\
\text { knnma için Avrupa Tarnm Fonu } \\
\text { enizcilik \& Ballkçllak Fonu } \\
\text { lim Eylemi } \\
\text { klim Evlemi Programı (LIFE) }\end{array}$ \\
\hline
\end{tabular}

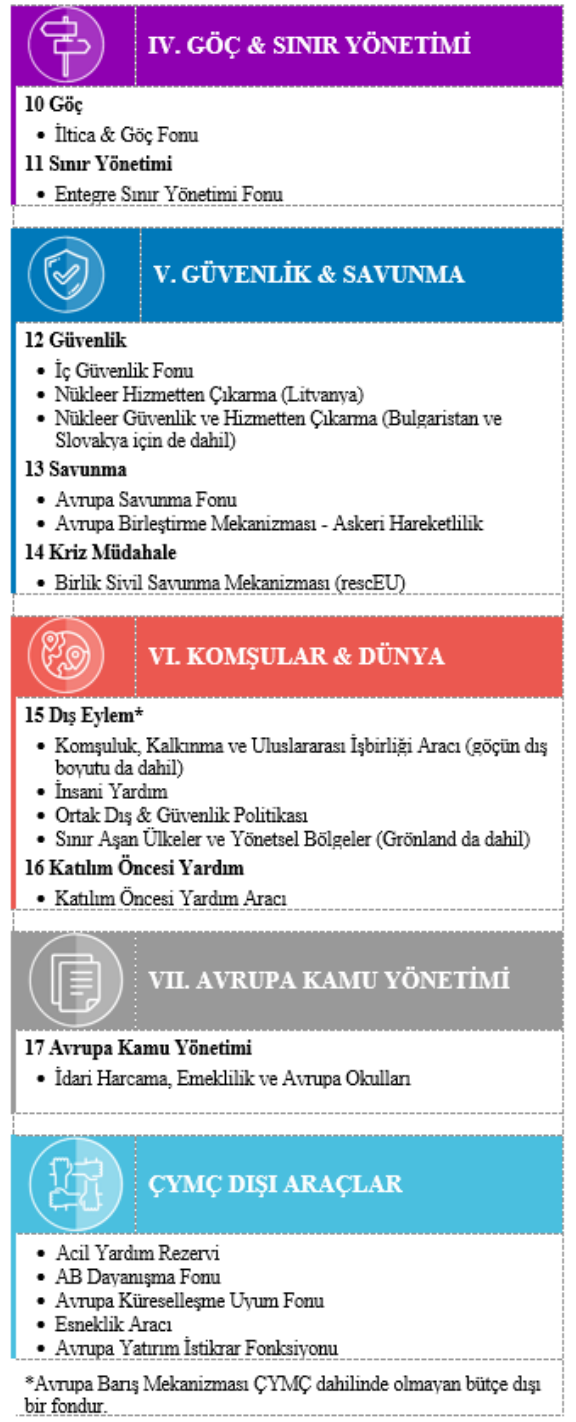

Şekil 4. 2021-2027 Bütçesi'nde Öncelikler ve Ana Başlıklar

Kaynak: European Commission, $2018 b$.

Bütçenin resmi yapısını resmeden bu sistem, uygulama söz konusu olduğunda ise resmin yalnızca belli bir kısmını sergilemektedir. Zira önceliklerin çoğunun karmaşık ve çok boyutlu olmasının yanı sıra tek bir programla bütün alanları yönetmenin olanaksızlığı nedeniyle yeni mali çerçevede birden fazla programdan yapılan yatırımların bir araya getirilmesi planlanmıştır. Nitekim dijital ekonomi, sürdürülebilirlik, güvenlik, göç, beşeri sermaye gibi önceliklerin yanı sıra KOBİ'lere ve inovasyona destek gibi kilit önem atfedilen öncelikleri entegre ve koordine edebilmek hedeflenmiştir. Böylelikle bu alanlar arasındaki etkileşimin basitleștirilmesi sayesinde yeni zorluklara karşı daha bütüncül ve daha tutarlı tepkilerin verilebileceği öngörülmüştür. Ortak bütçenin yapısına ve işleyişine dair yeni dönemde ön plana çıkan başlıca reform girişimleri ana hatlarıyla bu yöndeyken, harcama önceliklerinin her biri için tasarlanmış reformlar ve yeni programlar söz konusudur. Bunlar, Koruyan, Güçlendiren ve Savunan bir Birlik için Modern bir Bütçe olarak tanımlanan yeni ÇYMÇ’nin orijinal metni olan Komisyon tebliğine ek olarak, programların amaçları, tasarımı ve Avrupa katma değerine ilişkin ayrıntılı bilgiler sunan ek-rapordan ve bütçeye ilişkin muhtelif çalışmalar ortaya koyan diğer resmi belgelerden de yararlanmak suretiyle aşağıda incelenmektedir.

\subsubsection{Ortak Pazar, İnovasyon ve Dijitalleşme}

Ortak Pazar, İnovasyon ve Dijitalleşme başlığı, Birliğin temel öncelikleri çerçevesinde, araştırma ve yenilik, stratejik altyapı, ortak pazarın güçlendirilmesi ve stratejik uzay projeleri gibi stratejik alanlardaki yatııımları hızlandırmak, dijital dönüşümün ve gelecekteki büyümenin kilidini açmak, karbonsuzlaştırma ve demografik değişim gibi ortak zorlukların üstesinden gelebilmek için anahtar bir başlık olarak tasarlanmıştır. Bu doğrultuda yeni bütçede ilk ve tartı̧̧masız en dikkati çeken program, yeni araştırma programı olan Ufuk Avrupa (Horizon Europe) olarak karşımıza çıkmaktadır. Bilindiği gibi Birliğin çerçeve programları bilim ve teknoloji alanlarındaki ilerlemenin ve yakınsamanın Avrupa genelindeki lokomotifi olarak 1984 yılından bu yana uygulanmaktadır. Araştırma ve teknoloji geliştirme kapasitesini güçlendirmek, üniversite- 
sanayi işbirliğini teşvik etmek, üye ülkeler, programa asosiye ülkeler ve AB'nin işbirliği yaptığı diğer ülkeler ile AB politikaları kapsamında işbirliğini çeşitli alanlara taşımak hedefiyle yürütülen ve günümüzde de Birliğin küresel araştırma ve inovasyon konularında ön saflarda yer alabilmesi için devam ettirilen bu programlar, geniş kapsamlı bir bilimsel çerçeve içerisinde ar-ge ve yenilik faaliyetlerini desteklemek için kurulan özel bir fonlama metodu ile yürütülen bir sistem sunmaktadır (Avrupa Birliği Bakanlığı ve TÜBİTAK, 2016: 1-2). Ufuk 2020 için bir ara değerlendirme sunan Pascal Lamy başkanlığındaki üst düzey grup raporunda, rekabet gücünün, refah toplumunun ve Birliğin kendine özgü sosyal modelinin sürdürülebilirliği için ar-ge yatırımlarının bir önkoşul olduğu vurgulanmıştır (European Commission, 2018c). $\mathrm{Bu}$ bağlamda Ufuk Avrupa ile araştırmada mükemmeliyetin özendirilmesi, yeni prototiplerin geliştirilmesi, fikri mülkiyete yönelik maddi olmayan varlıklara (intangible assets) ve bilgi ve teknoloji transferi süreçlerine yönelik desteklerin sürdürülmesi hedeflenmektedir. Yeni bütçe tasarısında, Schumpeter'in kapitalizme içkin asli bir unsur olarak yaratıcı yıkım (creative destruction) kavramıyla açıkladığı dönüştürücü gücün doğasına ve iş döngülerine dair yaklaşımın (Schumpeter, 2010) piyasaya uyarlanmış bir versiyonu olan yıkıcı yenilikçilik (disruptive innovators) söylemine de vurgu yapıldığı görülmektedir. Bu noktada, mevcut yapı ve aktörleri yerinden eden yenilikçi süreçlerde ve pazar yaratıc1 inovasyonda Avrupa'yı öncü kılma hedefine yönelik yeni bir Avrupa Inovasyon Konseyi söz konusudur (European Commission, 2018d).

Avrupa Stratejik Yatırım Fonu'nun Avrupa genelinde özel yatırımları katalize etmedeki başarısını temel alan ve tamamen entegre olmuş bir yatırım fonu olarak planlanan InvestEU sayesinde merkezi yönetilen tüm finansal araçların tek bir yapıya bağlanması, bu yolla çakışmaların azaltılması, finansmana erişimin basitleştirilmesi ve idari yükün hafifletilmesi planlanmaktadır. Bu doğrultuda 15,2 Milyar Euro'luk bir mali destek ile InvestEU'nun, Avrupa genelinde 650 Milyar Euro'nun üzerinde bir ek yatırımı harekete geçirebileceği Komisyon tarafından ileri sürülmüştür.

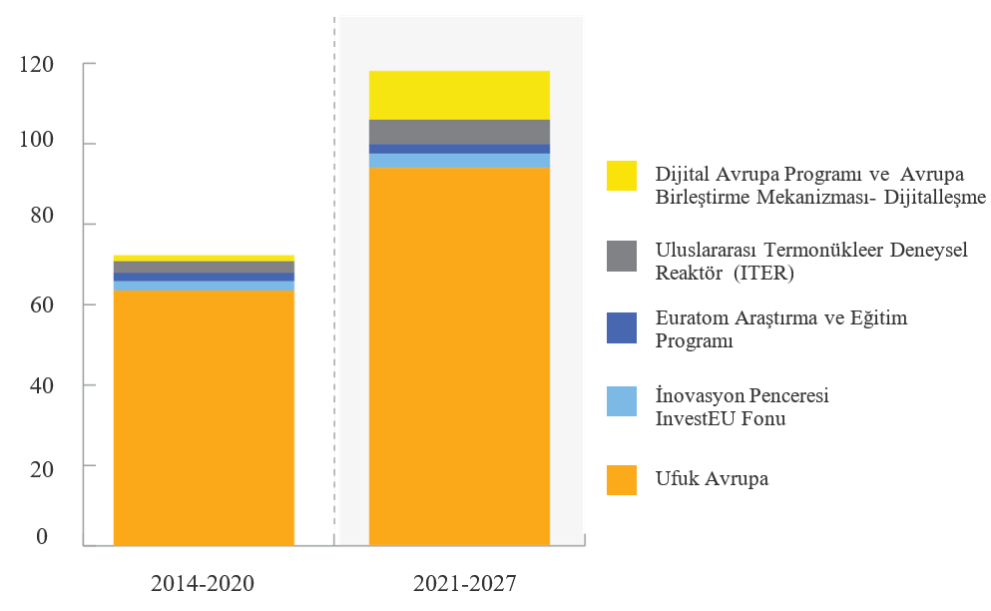

Şekil 5. AB'de Geleceğe Yatırım

Kaynak: European Commission, 2018 b.

Reforma tabi bir diğer araç olan Avrupa Birleştirme Mekanizması (Connecting Europe Facility) aracılığıla Birlik, Avrupa ötesi ulaştırmaya, dijitalleşmeye ve enerji ağlarına yönelik yatırımı sürdürürken, yeni dönemde alternatif yakıtlar altyapısının geliştirilmesi veya Dijital Ortak Pazar ve Enerji Birliği’nin temelini oluşturan sürdürülebilir ve akıllı şebekeler aracılığıyla ulaşım, dijitalleşme ve enerji altyapısı arasındaki sinerjiden daha iyi yararlanılması hedeflenmektedir. Ayrıca Uyum Fonu dâhilindeki ödeneğin 11,3 Milyar Euro'luk kısmı, Avrupa katma değeri yüksek ulaşım projeleri için Birleştirme Mekanizması'na aktarılmaktadır. Bunun yanı sıra, sosyal ve ekonomik boyutlarıyla dijital dönüşümü Birlik genelinde ve bütüncül bir yaklaşımla yönlendirebilmek için yeni bir Dijital Avrupa Programı (Digital Europe Programme) tasarlanmıştır. Teknolojik değişim ve dijitalleşmenin, toplumlar, endüstriler, üretim süreçleri, eğitim ve tüm yaşamsal faaliyetler üzerindeki dönüştürücü etkisi dikkate alındığında; endüstriyel dijitalleştirme, yapay zekâ, süper bilgisayarlar ve siber güvenlik gibi geleceğe kapı aralayan stratejik projeleri desteklemek ve dijitale yatırım yapmak asli konular haline gelmiştir. Bu bağlamda Birliğin yeni önceliklerinin başında gelen Dijital Ortak Pazar'ın tamamlanması da kaçınılmaz olarak bu yeni programın başarısı ile doğrudan bağıntılıdır. Bu da yeni dönemde ar-ge, inovasyon ve dijitale yönelik yatırımların üçte ikiye yakın bir oranla artırılmasını ve bu artışın, Avrupa Yapısal ve Yatırım Fonları ile desteklenen araştırma, yenilik ve dijitalleşme projeleriyle tamamlanmasını beraberinde getirmektedir.

\subsubsection{Uyum ve Değerler}

Uyum ve Değerler başlığı altında; bölgesel kalkınma ve uyum, EPB'nin tamamlanması ve vatandaşlar, sosyal uyum ve değerler alanlarına yönelik yatırımlar finanse edilecektir. Yeni mali çerçevenin programlar arasındaki bağı ve koordinasyonu güçlendirmesi beklenmektedir. Bu beklenti adı üzerinde "uyum” politikasının gerek kendi çatısı altında gerekse farklı programlarla daha verimli bağlantılar kurabilmesi için ayrıca dikkate alınmak zorundadır. Örneğin yeni 
dönemde, üye ülkelerin bütçe tarafından sağlanan garantiye ulaşabilmek için kullanımlarına tahsis edilen fonların bir kısmını diğer bir bütçe başlığında yer alan InvestEU fonuna aktarabilecekleri, benzer şekilde Ufuk Avrupa programı tarafindan kendi bölgelerinde uluslararası mükemmeliyet projeleri olarak belirlenen Mükemmeliyet Mührü projelerini finanse edebilecekleri bir esneklik sunulmaktadır. Bu ve benzeri örneklerin, altyapıya yapılan yatırımın araştırma ve yenilik, dijital ağlar, karbonsuzlaştırma, sosyal altyapılar ve beceriler gibi önemli alanlardaki diğer Birlik yatırımlarıyla doğru bir şekilde koordine edilmesine yardımcı olacağı öngörülmektedir (Kurtar ve Cengiz, 2019: 63).

Mevcut 2014-2020 bütçesi, AB'de bütçe krizi olarak 2010'da derinleşen küresel finans krizinin çalkantılı koşullarının etkisiyle, akılcı ve kapsayıcı büyüme önceliğine uygun olarak tasarlanmıştı. Öyle ki 2008 krizinin tetiklediği süreç, reel üretim ve ticaretteki daralma ile devam etmiş ve istihdam, gelir düzeyi ve diğer makroekonomik göstergelere yansıyan uzun dönemli bir ekonomik bunalıma yol açmıştı. En büyük hasar, resmi anlamda iflas eden Yunanistan'ın da dâhil olduğu PIIGS olarak adlandırılan (Portekiz, İspanya, İrlanda, Yunanistan, İtalya) çevre ekonomilerinde yaşanmıştı. Zaman içerisinde merkez ekonomilerde ve özellikle Euro Alanı'nda yayılan etkiler, parasal birliğin tartışmalı bir noktaya taşınmasına yol açmıştır (Cengiz, 2018: 254). Geniş çaplı bir üretim krizine dönüşen finansal kriz, ekonomik ve sosyal koşulları gerileten sonuçlar doğurmuştu. Yeni bütçe taslağında bu koşulların giderek iyileştiği ve istihdam başta olmak üzere yapısal dinamiklerin güçlenmeye başladığı savunulmakla birlikte, ekonomik krizin etkilerinin Avrupa'nın bazı bölgelerinde devam ettiği inkâr edilmemektedir. Nitekim küreselleşme ve dijital dönüşümün etkileri de dikkate alındığında bölgeler arası gelişmişlik makasının daha da açıldığı, Birlik içi eşitsizliklerin bu noktada derinleştiği ve bu nedenle ortak bütçenin, bir yandan sürdürülebilir büyümeye ve sosyal uyuma katkı sunmak ve öte yandan ortak değerler ile Birliğe aidiyet hissini ön plana çıkarmak gibi kayda değer bir rolü olduğunun altı çizilmiştir (Kurtar ve Cengiz, 2019: 61-62). Bölgesel gereksinimlerin daha çok gözetilmesi ve bölgeler arası işbirliklerinin artırılması hedeflenen 2021-2027 döneminde, yatırımların izlenmesi ve değerlendirilmesi ile denetleme ve kontrol işlemlerinin basitleştirilmesine yönelik değişiklik önerileri yer almaktadır (İKV, 2019: 18). Bu bağlamda, Avrupa Bölgesel Kalkınma Fonu, Avrupa Sosyal Fonu ve Uyum Fonu olmak üzere üç ana fon üzerinden işleyen Uyum Politikası'nın modernizasyonu ve bölgesel özellikleri daha çok gözeten ekonomik politika koordinasyonunu içeren Avrupa Sömestri ile bütçe bağlantısının güçlendirilmesi ön plana çıkmıştır. Nispi kişi başı milli gelir, fon tahsisinde temel ölçüt olarak kalırken; kaynakların yapısal olarak nispeten geri kalan bölgelere yönlendirilmesinin, gerçek manada bir "uyum” ve "yakınsama” için kaçınılmaz bir zorunluluk olduğu söylenebilir. Böylelikle, özellikle genç işsizliği ve istihdama yönelik genel sorunlar ile iklim değişikliği ve göçmenlerin kabulü/entegrasyonu gibi güncel zorlukların da bu başlık altındaki önemi tartışmasız bir hal almaktadır.

Komisyon'un AB bütçesinin geleceği üzerine Aralık 2017'de (European Commission, 2017b) yaptığ1 değerlendirmeye benzer şekilde bütçenin geleceğinin daha istikrarlı ve verimli bir Ekonomik ve Parasal Birlik oluşturma hedefinden ayrılamayacağı yeni mali çerçeve taslağında da vurgulanmıştır. Bu noktada Birliğin ortak para deneyiminin özellikle Avrupa'da bütçe krizi olarak yansıyan küresel kriz sürecinde zorlu bir sınavdan geçtiğini hatırlamak gerekmektedir. Bu sınav henüz sona ermediği gibi parasal birlik üyesi ülkeler arasındaki yapısal farklılıklar ve ekonomik uçurum devam ettiği müddetçe ve Birliğin mali bütünleşme ayağı mevcut durumdaki gibi eksik kaldıkça, olası yeni ekonomik şokların üye ülkeler arasındaki asimetriyi açığa vurmaya devam edeceği ortadadır. Bu zorluk bertaraf edilmeden, yani önce Birliğin bütünleşme dinamiklerinden kaynaklanan bu eksiklik giderilmeden, Birliğin sui generis bütçesinin tek başına EPB'nin akıbetiyle ilişkilendirilmesinin öncelikle bütünleşme pratiği açısından pek de somut anlamlar içermediği söylenebilir. Ayrıca, tüm üye ülkelerinin (opt-out veya derogasyon hakkını kullananlar da dâhil) parasal birliğin ve ekonomik/mali politikaların koordinasyonuna dair bir döngü olan Avrupa Sömestri’nin bir parçası olduğundan hareketle, ekonomik istikrar ve yakınsamanın ortak bir hedef oluşu, parasal birliği güçlendirecek olan araçları da ortak kılmakta ve genel finansal mimarinin bir parçası yapmaktadır.

Yeni mali çerçevede uyum politikası dâhilindeki güçlendirilmiş ve yeniden yapılandırılmış Avrupa Sosyal Fonu'nun, yaklaşı 100 Milyar Euro'luk bir meblağ ile uyum harcamalarında dörtte biri aşkın bir oranı temsil ettiği görülmektedir. Fonun temel öncelik alanlarındaki etkinliğini en üst düzeye çıkarmak için Avrupa Sosyal Fonu, Gençlik İstihdam Girişimi, Sosyal Haklardan En Yoksun Bireylere Yönelik Avrupa Yardım Fonu, İstihdam ve Sosyal İnovasyon Programı ve Sağlık Programı gibi mali destek araçlarının tek bir kapsamlı araçta toplanması uygun görülmüştür. Bu programların yanı sıra yeni mali çerçevede daha güçlü "gençlik" odă̆l (youth focus) önerisi sunulmuştur. Buna, Erasmus Plus'a ve Avrupa Dayanışma Mekanizması'na (European Solidarity Corps) ayrılan bütçenin iki katına çıkarılması yoluyla ulaşılması hedeflenmektedir. Böylelikle Birliğin en görünür ve başarılı pratiklerinden biri olarak addedilen Erasmus programının, gençlerin eğitimi ve hareketliliği için firsatlar sunmaya devam etmesi ve kapsayıcı bir yaklaşımla dezavantajlı geçmişleri olan daha fazla gence ulaşmak ve daha fazla gence eğitim veya çalışma firsatı vererek başka ülkelerin kapılarını açmak başlıca hedef olarak belirlenmiştir. Bu bağlamda yeni bütçe tasarısında Avrupa Sosyal Haklar Sütunu'nun tamamen uygulanması da dâhil olmak üzere Birliğin sosyal boyutunun güçlendirilmesinin önemine değinildiği görülmektedir. Daha önce de sosyal koruma hedefleri ve dolayısıyla Sosyal Haklar Sütunu hakkında Komisyon Başkanı Juncker tarafından, “AB'nin özünde her zaman bir sosyal proje olduğu ve bir tek pazardan fazlasını, bir para biriminden, yani Euro'dan fazlasını ifade ettiğ $i$ ” vurgulanmıştı (European Commission, 2017c). Bununla birlikte AB'nin sosyal haklar bağlamındaki yaklaşımlarında bu söylemlere tezat pek çok çelişkili yönelimin olduğu görülmektedir. Nitekim sosyal koruma sistemlerinin sürdürülebilir, yeterli ve adil olmasını temel hedef olarak belirlemiş olan (European Commission, 2017d) bu platformun, başlı başına özelleştirme, kuralsızlaştırma ve esnekleştirme uygulamalarıyla koşullandırılan atipik istihdam biçimlerinin doğurduğu işgücü aleyhine sonuçlara ve genç işsizliği gibi kronikleşmeye yüz tutan göstergelere yönelik herhangi bir gündeminin olmadığı anlaşılmaktadır. 
Bir diğer yenilik önerisinin, Haklar ve Değerler (Rights and Values) ile Adalet (Justice) programlarını içeren yeni bir Adalet, Haklar ve Değerler Fonu (Justice, Rights and Values Fund) olduğu görülmektedir. Komisyon, Avrupa toplumlarının aşırılık, köktencilik ve ayrımcılık gibi sosyal ve politik alanı ayrıştıran ve aşındıran hareketlere daha çok maruz kaldığı bir evrede, Avrupa'daki siyasi, sosyal, kültürel ve ekonomik yaşam için derin ve doğrudan etkileri olan adalet, hakkaniyet ve başlıca $\mathrm{AB}$ değerlerini (insan onuruna saygı, özgürlük, demokrasi, eşitlik, hukukun üstünlüğü ve insan hakları) teşvik etmenin, güçlendirmenin ve savunmanın her zamankinden daha önemli olduğunu ifade etmiştir. ${ }^{3}$ Ayrıca mevcut bütçede yer alan ve 2021-2027 döneminde de devam etmesi planlanan Avrupa Birliği Dayanışma Fonu'nun (European Union Solidarity Fund) ve Avrupa Küreselleşme Uyum Fonu'nun (European Globalisation Adjustment Fund) da güçlendirilmesi planlanmıştır (European Commission, 2018b).

\subsubsection{Doğal Kaynaklar ve Çevre}

Mali çerçevenin en büyük ve en ihtilaflı bileşeni, doğal kaynaklar ve çevre başlığıdır. Yeni dönemde bu başlık altında modernleştirilmiş tarım ve denizcilik politikaları, iklim eylemi ve çevrenin korunması, iklim fonlarının bütçenin geneline yaygınlaştırılması ve çevresel hedeflerin daha fazla entegrasyonu gibi hedeflerin ön plana alındığı görülmektedir. Yeni dönemdeki OTP reformları dâhilinde güvenlik, kalite, makul fiyat, besleyicilik ve çeşitlilik gibi unsurların desteklenmesini; çevre ve iklimi daha çok merkeze alan, tamamen sürdürülebilir bir tarım sektörüne geçişe ve kırsal alanların gelişimine yönelik destekleri içeren 365 Milyar Euro'luk ${ }^{4}$ kaynağın, çiftçilere yapılan doğrudan ödemeler ve kırsal kalkınma fonu olmak üzere iki sütun üzerinde devam edeceği anlaşılmaktadır. Bununla birlikte, gerek küresel gerekse bölgesel odaklı güncel zorluklar ve öncelikler açısından konuya yaklaşıldığında, küresel piyasalardaki öngörülemeyen gelişmeler ve/veya üçüncü ülkelerin gerçekleştirdiği uygulamalar nedeniyle tarım sektöründe oluşan özel bir şokun yol açtığı krizleri çözmek için yeni bir kriz rezervi oluşturulmasına dair zorunluluğun Komisyon tarafindan da kabul gördüğü taslak çerçeveden anlaşılmaktadır. Çiftçilere yapılan doğrudan ödemeler, OTP'nin önemli bir bileşeni olmaya devam etmekte ve fakat daha sistematik ve hedefleri daha belirgin bir çerçeveye alınmaktadır. Daha dengeli bir dağıtımın teşvik edilmesi ve alınan miktarlar ya da aşırı ödemelere çiftlik düzeyinde zorunlu bir sınır getirileceği görülmektedir. Bunun anlamı, desteğin küçük ve orta ölçekli çiftliklere ve muhtemelen kırsal kalkınmaya yeniden tahsisinin ön plana çıkmasıdır. Yine doğrudan ödeme düzeylerinde üye ülkeler arasında hektar başına Birlik ortalamasına doğru yakınsamaya yönelik adımların atılmaya devam edeceği vurgulanmaktadır. Bunun yanı sıra yeni dönemde, doğrudan ödemeler için koşulluluğun güçlendirilerek çevre politikalarına uygun, iklim ve çevreye yararlı faaliyetler için kırsal kalkınma finansmanının önemli bir bölümünü koruyan ve performansa dayalı ve stratejik bir çerçevede doğrudan ödemeler için bütçeye gönüllü eko-düzenleri getiren daha yüksek düzeyde bir çevre ve iklim hedefi gerekliliği vurgulanmıştır (European Commission, 2018b).

Avrupa Denizcilik ve Balıkçılık Fonu ile Balıkçılık ve su ürünleri yetiştiriciliğinde mavi ekonomiyi, turizmi, temiz okyanus enerjisini/mavi biyo-teknolojiyi teşvik ederek; hükümetleri, endüstriyi ve paydaşları, deniz ortamını korurken sürdürülebilir bir büyümeyi hızlandırmak için ortak yaklaşımlar geliştirmeye cesaretlendirerek, gerçek Avrupa katma değerinin yaratılabileceği ifade edilmiştir. Ayrıca Komisyon, çevre ve iklim eylemi için köklü bir program olan $L I F E$ programını sürdürmeyi ve güçlendirmeyi teklif etmiş ve aynı zamanda enerji verimliliği ve temiz enerjiyi teşvik eden önlemlerin desteklenmesine vurgu yapmıştır. Hedeflenen doğa koruma girişimlerine destek olmak adına, doğa ve biyoçeşitlilik yatırımlarının finanse edilmesinde Uyum Politikası ve OTP ile sinerjinin güçlendirilmesi gerektiğinin altı çizilmiştir. Daha genel olarak Paris Anlaşması ve Birleşmiş Milletler Sürdürülebilir Kalkınma Hedefleri de dikkate alındığında Komisyon'un, AB harcamalarının \%25'inin iklim hedeflerine katkısını içeren ve tüm AB programları üzerinde oluşturulacak bir iklim kaynaştırması hedefini ortaya koyan daha iddialı bir öneri sunduğu görülmektedir. ${ }^{5}$

\subsubsection{Göç ve Sınır Yönetimi}

Bu yeni başlık altında "göç yönetimine kapsamlı bir yaklaşım” ve "dış sınırların yönetimini güçlendirmek" gibi iki asli yatırım önceliğinin finanse edilmesi tasarlanmıştır. Komisyon’a göre mülteci hareketlerini yönetmenin zorlukları, Avrupa düzeyinde harekete geçmeyi de zorunlu hale getirmiş ve AB bütçesi göç krizinin çeşitli boyutlarına ortak bir müdahale için gerekli finansmanın sağlanmasında kilit bir role sahip olmuştur. Bu doğrultuda, dış sınırların güçlendirilmesi, Birlik düzeyinde iltica sisteminin iyileştirilmesi ve göçmen meselelerinin koordineli yönetimi konularında entegrasyonu ileri

\footnotetext{
${ }^{3}$ Yeni bütçede yer tutan hukukun üstünlüğüne yönelik koşulluluk yaklaşımının, fiilen Polonya ve Macaristan (kısmen de Romanya, Slovakya ve Malta) gibi uyum fonu başta olmak üzere Birlik bütçesinden kayda değer miktarda mali destek alan, fakat son dönemde Birlik değerleriyle çelişen uygulamalarıyla gündeme gelen üye ülkeler düşünülerek bütçe taslağına yansıtıldığı anlaşılmaktadır. Zira söz konusu yaklaşıma karşı en hızlı tepki ve itirazlar yine bu ülkelerden gelmiştir.

${ }^{4}$ Buna ek olarak, Ufuk Avrupa dâhilinde gıda, tarım, kırsal kalkınma ve biyo-ekonomi konularında araştırma ve inovasyonu desteklemek üzere 10 Milyon Euro'luk bir tutar öngörülmektedir (European Commission, 2018b).

${ }^{5}$ Komisyon'un bu noktadaki kararlı söylemlerine karşın, Londra Ekonomi Okulu bünyesindeki İngiliz Grantham İklim Değişikliği ve Çevre Araştırmaları Enstitüsü tarafından yayınlanan 2018 yılı raporuna göre, anlaşmanın öncüsü Fransa dâhil olmak üzere hiçbir AB üyesi ülkenin küresel ısınmaya neden olan sera gazlarının salınımını önlemek için sorumluluklarını tam anlamıyla yerine getirmediği tespit edilmiştir. Bunun yanı sıra söz konusu bilimsel raporda, küresel ısınmayla mücadeleye yönelik 2015 yılında imzalanan Paris İklim Anlaşması'na taraf 195 ülkeden yalnızca 16'sının anlaşma hükümlerine tamamen uyduğu ifade edilmiştir. İklim Anlaşması'nın imzalanmasının ardından sera gazı salınımına yönelik önlemlerin oldukça katı olduğunu savunan ve Almanya başta olmak üzere sanayisi gelişmiş bazı ülkelerin, kriterlerin daha da katılaştırılmasına karşı çıktı̆̆ı da bilinmektedir (The London School of Economics and Political Science, 2019; Kurtar ve Cengiz, 2019: 69-70).
} 
taşımak için mevcut desteğin artırılması teklif edilmiştir. Dış sınırların etkin bir şekilde korunmasının, Birlik içinde kişilerin ve malların serbest dolaşımı için güvenli bir alanın sağlanması açısından bir ön koşul olduğu ve bu koşulun kişilerin ve malların akışının uygun şekilde yönetilmesini ve gümrük birliğinin bütünlüğünün korunmasını da kapsadığ1 vurgulanmıştır. Yeni ve entegre edilmiş yeni bir Sınır Yönetim Fonu aracılığıyla Birliğin ortak dış sınırlarının güvence altına alınmasına yönelik sorumluluklar konusunda üye ülkelere güçlendirilmiş bir destek oluşturacağı ve bu fonun, sınır yönetimi, vize ve gümrük kontrol ekipmanlarını kapsayacağı ifade edilmiştir. Dış sınırlardaki gümrük kontrollerinin yerine getirilmesinde eşitliği sağlamaya yardımcı olması öngörülen bu fonun, coğrafya, kapasite ve kaynak farklılıkları nedeniyle üye ülkeler arasındaki mevcut dengesizlikler dikkate alınarak sağlanması ve ayrıca gümrük kontrollerini güçlendirmekle kalmayarak, aynı zamanda meşru ticareti kolaylaştırarak güvenli ve verimli bir gümrük birliğine katkıda bulunması beklenmektedir. Dış sınırların yönetimi, göç ve mülteci akışları için ayrılan AB bütçesinin, 2014-2020 dönemi için ayrılan 12,4 Milyar Euro'ya kıyasla, toplamda yaklaşık 33 Milyar Euro’ya ulaşarak önemli ölçüde güçlendirilmesi planlanmıştır.

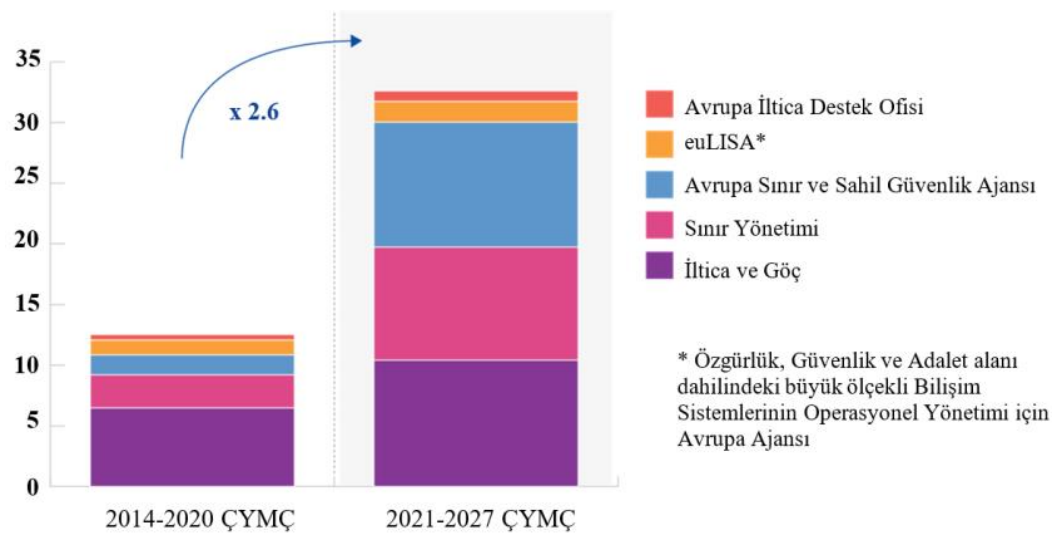

Şekil 6. Göç ve AB Dış Sınırlarının Korunması

Kaynak: European Commission, $2018 b$.

Küresel çalkantıların yanı sıra Avrupa kıtasındaki demografik dinamikler ve süregiden dengesizlik eğilimi de göz önüne alındığında, göçün, Birlik için uzun vadede bir zorluk olmaya devam edeceği anlaşılmaktadır. Bu sürecin üye ülkeler tarafından AB'nin mali ve teknik desteği ile daha iyi yönetilebileceği ortadayken, Birlik bütçesi de, sığınmacı ve göçmen meselelerinin yönetimini desteklemek ve Avrupa'ya ulaşmaya çalışan insanların hayatlarını kurtarmak için arama kurtarma kapasitelerinin geliştirilmesinde, geri dönüşlerin etkin yönetiminde ve üye ülkelerin ayrı ayrı kapasitelerinin ötesinde koordine bir yanıt gerektiren diğer eylemlerde hayati önem taşımaktadır. Bu doğrultuda Komisyon, ulusal otoritelerin çalışmalarına, AB topraklarına girdikten hemen sonraki dönemde sığınmacıları ve göçmenleri kabul etmenin yanı sıra ortak bir iltica ve göç politikası geliştirmek ve etkin geri dönüşler sağlamak için destek vermek üzere Siğınma ve Göç Fonu'nu güçlendirmeyi teklif etmiştir. Uyum Politikası'nın, kabulün ilk aşamasından itibaren uzun vadeli entegrasyonu kolaylaştırmak için destek sağlayacağı ifade edilmiştir. Dış politika altındaki araçların, göçün temel nedenlerini ele almak ve üçüncü ülkelerle göç yönetimi ve güvenliği üzerine iş birliğini desteklemek suretiyle, göç konusunda ortaklık çerçevesinin uygulanmasına katkı sunması planlanmıştır. Nitekim bu girişimlerin tam entegre bir $\mathrm{AB}$ sınır yönetim sisteminin merkezinde güçlü ve tam operasyonel bir Avrupa Sınır ve Sahil Güvenliği (FRONTEX) ile tamamlanması gerektiği vurgulanmıştır. Komisyon, mali sürenin sonuna kadar yaklaşık 10.000 sınır polisinden oluşan daimi bir birlik kurmayı teklif etmiş; ayrıca, üye ülkelerde ulusal sınır polisleri bileşeninin artırılması için finansal destek ve eğitim sağlamayı taahhüt etmiştir. Bunun aynı zamanda operasyonel kapasitenin artırılması, mevcut araçların güçlendirilmesi ve sınırlar, göç yönetimi ve güvenlik için Birlik çapında bilgi sistemlerinin geliştirilmesi için önemli bir firsat sunacağı ifade edilmiştir (European Commission, 2018b).

\subsubsection{Güvenlik ve Savunma}

$\mathrm{Bu}$ başlık altındaki öncelikli yatırım alanları; Avrupa vatandaşlarının emniyet ve güvenliği, Avrupa'nın savunma kapasitesinin artırılması ve krize müdahale olmak üzere üç noktada belirginleşmektedir. Bu noktalardan hareketle Komisyon, terörist saldırılar, yeni organize suç türleri ve siber suçlar başta olmak üzere son yıllarda yoğunlaşan ve çeşitlenen güvenlik tehditleri karşısında sınır ötesi boyutun önemini vurgularken; güçlü ve doğru koordine edilmiş bir karşı eylem stratejisinin taşıdığı önemin altını çizmiştir. Avrupa'da iç güvenlik zorluklarının ötesinde, hiçbir üye ülkenin salt kendi başına karşı koyamayacağı karmaşık dış tehditlere de maruz kaldığını hatırlatan Komisyon, vatandaşlarını korumaya hazır olmak adına Birliğin, stratejik özerkliğini geliştirmek ve savunmaya yönelik iyi tasarlanmış modern araçlar inşa etmek için bir değişikliğe gereksinimi olduğunu ifade etmiştir. Ulusal makamlar arasında etkin bir iş birliği sağlamak için ağlar ile ortak sistemler oluşturmak ve Birliğin bu güvenlik tehditleriyle yüzleşme kapasitesini geliştirmek

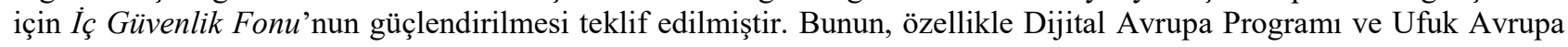


aracılığıyla dijital teknolojilere, altyapılara ve ağlara, araştırma ve inovasyonun yanı sıra siber suçlara karşı hedeflenen savunmaya odaklanmış tüm programlardaki siber güvenliği güçlendirme girişimleriyle tamamlanması öngörülmüştür. Ayrıca, Avrupa Polis Ofisi'nin (Europol) güçlendirilmesi, bu doğrultuda ulusal makamların çalışmalarını destekleme becerisinin artırılması ve güvenlik tehditlerine karşı ortak bir Avrupalı tepkisi oluşturulması planlanmıştır.

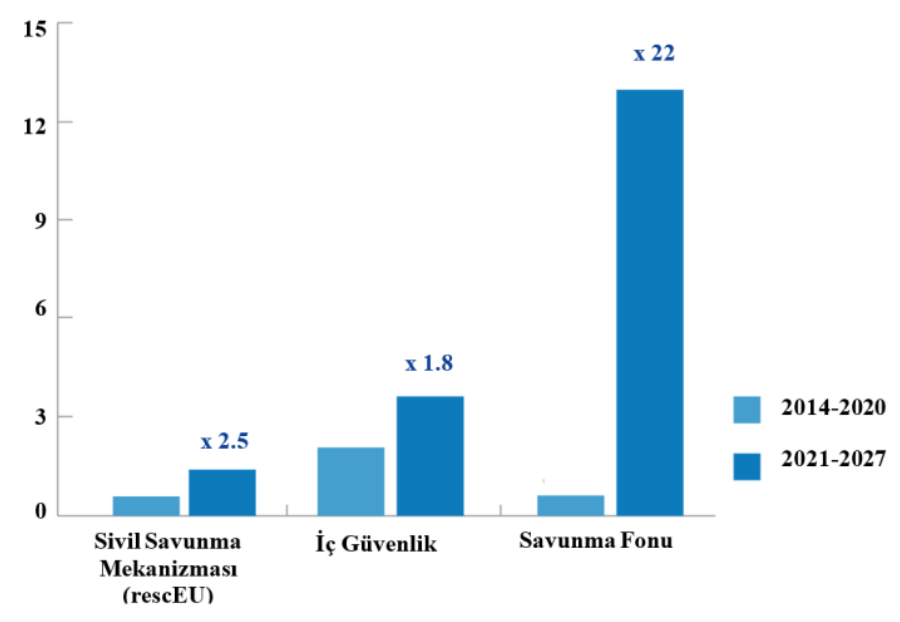

Şekil 7. Güvenlik ve Savunmada Kademe Atlama

Kaynak: European Commission, $2018 b$.

Yeni bütçe tasarısında, Savunma alanında Birliğin, NATO çalışmalarında daha fazla sorumluluk alması, bunun yanı sıra ortak güvenliğe ilişkin zorluklarla başa çıkabilmek için savunma kabiliyetlerinin geliştirilmesi ve Birlik genelinde savunma endüstrisinin rekabetçi ve yenilikçi kapasitesinin artırılması hedeflerine yönelik güçlendirilmiş bir Avrupa Savunma Fonu'nun devrede olacağı anlaşılmaktadır. Bunların yanı sıra doğal ve insan kaynaklı felaketlere karşı Birliğin operasyonel kapasitesinin artırılması ve bu artışın gerek Birlik-içi gerekse Birlik-dışı acil durumlar için mali çerçevede belirlenen tavan değerlerin üzerinde finansal araçlar sağlayacak güçlendirilmiş bir Sivil Koruma Mekanizması (rescEU) ve genişletilmiş Acil Yardım Rezervi ile gerçekleştirilmesi planlanmıştır. Bunların yanı sıra kriz ve acil durumlarda kullanılacak İltica ve Göç Fonu ve Iç̧ Güvenlik Fonu gibi bazı programlardaki rezervlerin sürdürülmesi beklenmektedir (European Commission, 2018b).

\subsubsection{Komşular ve Dünya}

Yakın ve uzak coğrafyalara yayılan tüm dış eylemler ve Birliğe katılmaya aday ülkelere yönelik mali yardımlar olmak üzere iki öncelikli alana yapılan yatırımlar bu harcama başlı̆̆ altında toplanmıştır. İlk göze çarpan boyut, Dlş ve Güvenlik Politikası Küresel Stratejisi, gözden geçirilmiş Avrupa Komşuluk Politikası ve yeni Avrupa Kalkınma Mutabakatı çerçevesinde Birliğin dış eylemlerine dair zorlukların, ortak bütçenin dışa yönelik etkinliğini artırmak adına bir takım yeniliklerin gerçekleştirilmesini kaçınılmaz kılmış olmasıdır. Ayrıca, Sürdürülebilir Kalkınma Hedefleri ve Paris İklim Anlaşması'nın yanı sıra göç konusunda üçüncü ülkelerle yapılan Ortaklık Çerçevesi'nin etkin yönetilebilmesi için dış politik eylemlerin iç politika ile daha koordineli olması hedeflenmiştir. Birliğin dış eylem araçları için önerilen yeni mimarinin, gerek coğrafi boyut dikkate alındığında Avrupa, Afrika ve Doğu Balkanlar’ı coğrafi anlamda, güvenlik, göç, iklim değişikliği ve insan hakları gibi sorunları ise tematik anlamda ön plana çıkaran ve stratejik önceliklere odaklı olacağ vurgulanan dış eylem araçlarına ilişkin yeni bir mimarinin hedeflendiği görülmektedir. Bu bağlamda mevcut araçların büyük çoğunluğunun daha kapsamlı bir Komşuluk, Kalkınma ve Uluslararası Isşbirliği Aracı'nda toplanması planlanmıştır. Bu yeni finansal mimariye bugüne kadar Birliğin Afrika, Karayip ve Pasifik ülkelerine ve denizaşırı ülkeler ve yönetsel bölgelere yardım sağlamadaki ana aracı olan AKF'nin de dâhil edilmesi, önemli bir sadeleştirme reformu olarak göze çarpmaktadır. Bu entegre yapının, coğrafi bölge başına tahsis edilen bütçeyi korumasının yanı sıra müdahale konusunda daha çok esneklik ve Birliğin önceliklerine yönelik daha çok seçenek sunması hedeflenmektedir. Bütçe taslağında Avrupa Dış Yatırım Planı ve Avrupa Sürdürülebilir Kalkınma Fonu üzerinde şekillenen yeni dış yatırım mimarisinin, istikrar ve göç konularında ortaya çıkabilecek acil önceliklere refleks gösterebilmesi ve daha esnek olabilmesi adına yeni zorluklar ve öncelikler desteğini de içereceği ifade edilmiştir. Ayrıca, bilindiği gibi Katılım Öncesi Yardım Aracı (IPA) ile Türkiye gibi aday ülkeler ve potansiyel aday ülkeler katılım kriterlerini yerine getirme yolunda desteklenirken, bunun da ötesinde yakın bölgelerin istikrarı, güvenlik ve refahının sağlanması ve böylelikle Birliğin genel hedeflerine ulaşması kolaylaşmaktadır. Yeni bütçe taslağına bakıldığında IPA'nın, Batı Balkanlar Stratejisi bağlamında konumlandırılacağı ve Türkiye açısından ise ilişkilerin seyrine göre koşullu bir finansman sürecinin işletileceği anlaşılmaktadır. 


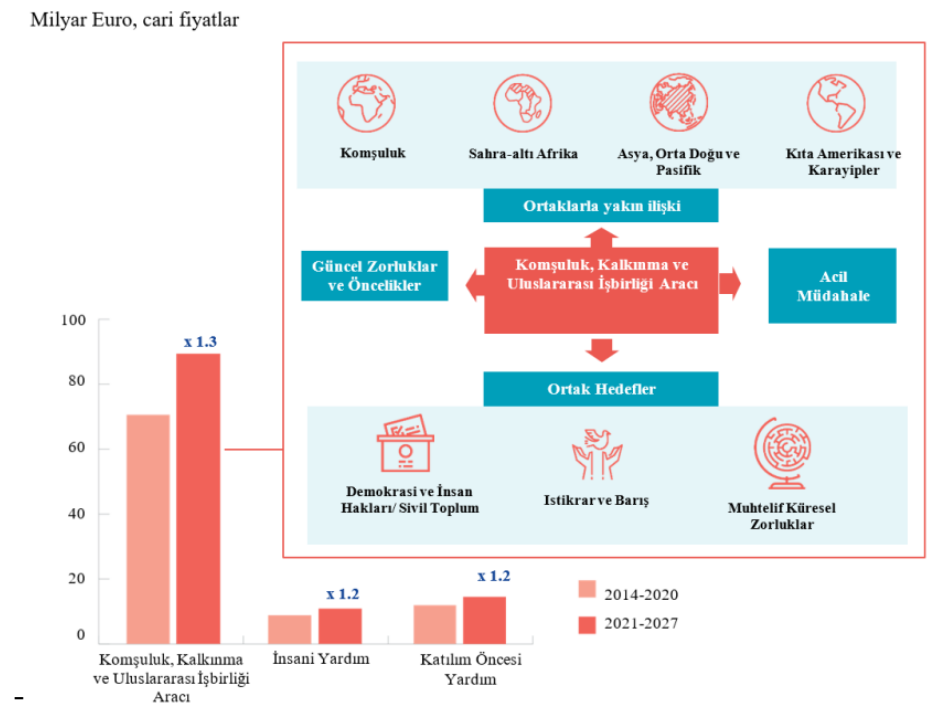

Şekil 8. Güçlü Bir Küresel Aktör olarak Avrupa

Kaynak: European Commission, $2018 b$.

Yeni bütçe tasarısında, Güçlendirilmiş İnsani Yardım Aracı ile Birliğin insani yardımda öncü bir rol alma gayretinin devam edeceği ve insan hayatına ve haklarına yönelik olumsuz gelişmelerin doğurduğu sonuçlara karşı entegre bir yardım mekanizmasının önemsendiğinin altı çizilmiştir. Bununla birlikte, bu harcama başlığına ve Birliğin küresel eylemlerinin etkinlik ve sürekliliğine dair başlıca idari zorluğun, dış güvenlik ve savunma alanındaki tüm Birlik faaliyetlerinin fonlanmasını engelleyen Birlik antlaşmaları olduğu görülmektedir. Bu zorluğu aşabilmek adına Dışişleri ve Güvenlik Politikaları Yüksek Temsilciliği tarafından ayrı bir bütçe dışı finansman mekanizması olan Avrupa Barış Aracı'nın kullanılabileceği ifade edilmiştir. Bu Araç sayesinde, Ortak Güvenlik ve Savunma Politikası görevlerine ilişkin manevra kabiliyetindeki mevcut açığın kapatılması ve üçüncü ülkelere, uluslararası ve bölgesel kuruluşlara savunma desteğinin ve askeri yardımın yönlendirilebilmesi hedeflenmektedir (European Commission, 2018b).

\subsubsection{Avrupa Kamu Yönetimi}

Yeni bütçede bu başlık, tüm Avrupalıların hizmetinde verimli ve modern bir kamu yönetimine yönelik temel yatırım alanları doğrultusunda Birliğin önceliklerini yerine getirmesinde ve ortak Avrupa çıkarına uygun politikaların ve programların uygulamasında kritik bir öneme sahiptir. Avrupa kamu yönetimi, ulusal ve hatta birçok bölgesel ve yerel yönetimle karşılaştırıldığında oldukça mütevazı bir boyutu temsil etmekle birlikte, son yıllarda Avrupa idaresinin köklü bir reform sürecinden geçtiği de bir gerçektir. Dolayısıyla mevcut ÇYMÇ’ye ilişkin Aralık 2013'teki anlaşmanın bir parçası olan personel yönetmeliği reformu ile uygulamaya konulan verimlilik önlemlerinin (significant efficiency measure $)^{6}$ yanı sıra kamu kurumları açısından mevcut personel sayılarını \%5'e kadar düşürme taahhüdü söz konusu olmuştur. Komisyon, bu taahhüdünü yerine getirirken; diğer kurum ve daireler de bu azaltmayı uygulamaktadır. Böylece Komisyon personelinin tüm Avrupa organlarındaki nispi payı azaltılmaktadır. Nitekim ortak bütçeyi denetlemekle yetkili organ olan Avrupa Sayıştayı da tüm kurum ve kuruluşların bu taahhüdü büyük ölçüde yerine getirdiği sonucuna varmıştır. Komisyon'un reform olarak sunduğu bu uygulamalar yoluyla, çalışma saatlerinde artış, yeni öncelik alanlarında yeni görevlerin üstlenilmesi, göç ve mülteci krizi gibi öngörülemeyen zorluklara odaklanılmasının hedeflendiği ifade edilmiştir.

Yeni dönemde, Avrupa kamu yönetiminin verimlilik ve sinerji boyutlarıyla etkin işleyişinin yanı sıra, yönetime temel işlevleri yerine getirebilmesi için yeterli kaynağın sağlanması, bilişim teknolojilerine yatırımın ve kamu binalarının iyileştirilmesine duyulan gereksinimin devam edeceği ifade edilmiştir. Özellikle Birleşik Krallık’ın ayrılışının, idare içindeki bazı işlevlerin sınırlı bir şekilde yeniden yönlendirilmesine yol açacağı, bununla birlikte faaliyetlerin kapsamının değişmeyeceği ve bütçenin yeni öncelik alanlarına yoğunlaşacağı öne sürülmüştür. Bu kapsamda, 2020 yılı idari harcamaları için belirlenen tavan, genel ÇYMÇ’nin \%6,7'sine tekabül etmektedir. Bunun, tüm Birlik kurumlarının idari harcamalarını, emekli maaşlarını ve Avrupa Okulları'nın maliyetlerini kapsadığı anlaşılmaktadır. Bununla birlikte yeni mali planda, güçlü bir Birlik söyleminden hareketle, Avrupalıların yararına katma değer üreten verimli ve hızlı kamu hizmetlerine olan gereksinimden ötürü, hâlihazırda daha fazla azaltmaya gitmek yerine idari harcamaların mevcut düzeyde sürdürülmesinin teklif edildiği görülmektedir (European Commission, 2018b).

\footnotetext{
${ }^{6} \mathrm{Bu}$ reformlar, tazminat olmaksızın haftada 40 saate kadar çalıșma süresinin artması, sekreterlik ve büro ișleri için daha ılımlı bir ücret skalasının oluşturulması ve yıllık izinlerin azaltılmasıyla birlikte iki yıllık bir maaş dondurulması içeriyordu. Reform ayrıca, kariyer sonu ücretlerindeki düşüş, daha yüksek bir emeklilik yaşı ve emeklilik tahakkuk oranının azaltılması yoluyla emeklilik haklarını olumsuz yönde ve önemli ölçüde etkilemiştir (Bkz: European Commission, 2018b; Kurtar ve Cengiz, 2019: 77).
} 


\section{Sonuç ve Değerlendirme}

$\mathrm{AB}$, üretim faktörlerinin serbest dolaşımının yanı sıra ortak bir para birimine geçişi sağlayabilmiş uluslarüstü bir sistemi temsil etmektedir. Bununla birlikte bu sistem, aralarında ekonomik ve mali açıdan derin yapısal ve politik farklılıklar bulunan ülke ekonomilerini tek bir çatı altında toplamaktadır. Birlik çatısı altında, bir tarafta Almanya başta olmak üzere Hollanda, Avusturya, İsveç ve Danimarka gibi bütçe fazlası veren kuzey ülkeleri, öte tarafta PIIGS gibi kamu borçları ve bütçe açıklarıyla kırılgan güney ekonomileri yer almaktadır. Siyasi ve tam ekonomik bütünleşme yolundaki başlıca zorluğu ifade eden bu çelişkili yapı, on yıllardır ortak politika ve araçlarla aşılmaya çalışılmasına rağmen varlığını sürdürmektedir. AB’nin, bu zorluğu aşabilmek adına ortak politikalarını seferber edebildiği en kapsamlı ve işlevsel aracı ise uzun vadeli bütçesidir. Bütünleşme pratiğinin asli bir aracı olmasının yanı sıra halklar üzerindeki doğrudan etkisi de göz önünde bulundurulduğunda ortak bütçenin, Birliğin varoluşu açısından taşıdığı önem tartışmasızdır. Bunun yanı sıra, yapısı ve evrimi itibariyle kendine özgü bir bütünleşme örneği olan AB'nin, tüm bileşenlerine ve politikalarına işlemiş olan bu özgünlüğü ortak bütçesine de yansımıştır. Bu nedenle geçmişten bugüne ÇYMÇ’ler, Avrupa bütünleşmesinin dinamikleriyle ve politik öncelikleriyle koşut bir gelişim çizgisi izlemiştir.

Yeni ÇYMÇ, yapısal olarak yalnızca AB'nin harcama planına ilişkin bir sistematiği değil, aynı zamanda politik duruşuna dair dönemsel önceliklerini yansıtan bir belge sunmaktadır. Nitekim yeni dönemdeki muhtelif başlıkların adlandırılmasında Avrupa 2020 Stratejisi'nde kullanılan terminolojinin de dönüştüğü, örneğin Akılcı ve Kapsayıcı Büyüme olan ağırlık merkezinin yavaş yavaş dijital ekonomi, göç, sınır yönetimi ve savunma gibi diğer önceliklere doğru dağıldığı anlaşılmaktadır (European Parliament, 2019a). Bu doğrultuda, "Koruyan, Güçlendiren ve Savunan bir Birlik için Modern bir Bütçe" söylemiyle başlayan yeni dönem, başlıkların ve programların uygulamada optimum sonucu verebilmesini, diğer bir deyişle verimliliği merkeze alarak planlanmıştır. Bununla birlikte bu tasarı, Birlik açısından güncel gelişmelerden ve zorluklardan beslenen bir takım çelişkiler de barındırmaktadır. Bu çelişkilerin aşılarak siyasi önceliklerin desteklenebilmesi ve anlaşmalı veya anlaşmasız bir Brexit'in finansal sonuçlarının bütçede dengelenebilmesi için Komisyon ve Parlamento arasında nihai bir uzlaşının sağlanması kritik bir önem taşımaktadır. Bunun yanı sıra Konsey'in ve dolayısıyla üye ülkelerin yedi yıllık yeni dönemin zorluklarına dair tutumu ve ülkeler/kurumlar arası uyumun boyutu, yeni bütçenin sahaya yansıyabilmesinde, yani uygulamada sonuç verebilmesinde belirleyici olacaktır.

Bununla birlikte, Komisyon'un ve bazı üye ülkelerin, bütçelemeye dair süreçleri Birliğin demokratik değer ve ilkelerine saygı çerçevesinde koşulluluk prensibine bağlama yönündeki olumlu iradesi, Birliğin Doğu ve Batı ülkelerindeki mevcut bölünmeleri daha da derinleştirebilecek nüveler içermektedir. Öte yandan, Fransa'nın öncülüğünde Komisyon tarafindan teklif edilen ve kaynakların (bütçenin \%2,3'ü olmak üzere) makro ölçekte istikrarı sağlayacak ve ani şoklara karşı koyacak bir kuruma tahsis edilmesini içeren plana; mali politika alanında her ülkenin kendi sorumluluğunu taşıması gerektiğini savunan başta Hollanda ve Finlandiya olmak üzere diğer üye ülkelerce karşı çıkıldığı görülmektedir. Yeni bütçeye yönelik tartışmalar, Avrupa finansmanını reforme etmek için bir fırsat sunarken, aynı zamanda ülkelerin ulusal düzeydeki harcamaları ile üretemeyeceği katma değerin, Avrupa düzeyindeki paylaşım ve dağıtım ilişkileriyle sağlanabileceğini düşündürmektedir. Bununla birlikte, harcamaların Birliğin siyasi önceliklerini yeterince yansıtması için, ortak kaynakların tahsisinde önemli değişikliklere gereksinim duyulacak ve ülkelerin verdikleri ile aldıkları arasındaki farka yani net dengelere odaklanmayı bırakmaları gerekecektir (Kurtar ve Cengiz, 2019: 82-83). Bunların yanı sıra, EPB'de yer alan ülkeler ile henüz ortak paraya geçiş sürecini tamamlamamış veya opt-out hakkını kullanmış üye ülkeler arasında, ortak bütçeye dâhil edilmesi planlanan "Euro Alanı Bütçesi” konusunda fikir ayrılıkları mevcuttur. Harcama önceliklerinin AB liderleri ve Euro Grubu tarafından belirlenmesi öngörülen bu yeni bütçe kaleminin, üye ülkelerin ekonomik yakınlaşmasını ve rekabetçiliği destekleyerek, EPB'yi güçlendireceği öne sürülmektedir. Fransa ve Almanya'nın öncülüğünde planlanan ve 2021 yılında devreye girmesi öngörülen bu tamamlayıcı bütçenin öncelikleri ve mali teşvik yapısına yönelik Euro kullanmayan Polonya gibi ülkelerin ikna edilmesi gerekecektir.

Yeni dönemsel önceliklerin finanse edilebilmesi için Parlamento, Komisyon teklifinden farklı olarak, Birlik milli gelir katkı oranını \%1,3 düzeyine yükselten ve \%16,7'lik bir artışa karşılık gelen daha güçlü bir bütçeyi savunmaktadır. Böylece yeni önceliklerin finansmanı için bütçede OTP ve Uyum Politikası'na ayrılan kaynaklar azaltılmaksızın, Ufuk Avrupa, Erasmus Plus, LIFE gibi programlarda ve göç, savunma, komşuluk gibi öncelik alanlarındaki muhtelif fonlarda daha büyük artışların gerçekleştirilmesi gerektiğinde 1srarcıdır. Bunlardan daha önemlisi, 2021-2027 döneminde iklim hedeflerine yönelik Birlik katkısının, ÇYMÇ harcamalarının minimum \%25'ini ve dönem bitmeden \%30'unu kaplaması gerektiği konusunda kritik bir tutum almaktadır (European Parliament, 2019b). Bununla birlikte Parlamento ve Komisyon'un, ilave fonlar, Birlik rezervi gibi mali çerçeveye esneklik kazandıracak olan araçlar, hukukun üstünlüğünü koşullandıran yeni mekanizma, kalkınma fonunun bütçeye aktarılması ve öz kaynaklar sisteminin reforme edilmesi gibi başlıca konularda net bir biçimde uzlaşı halinde olduğu görülmektedir (European Parliament, 2019a). Sonuç olarak, yeni mali çerçeve müzakerelerinin nihai çıktısı, 27 üyeli yeni yapının güçlü bir şekilde yönetilmesine dair kararlılığının bir yansıması, diğer bir deyişle bir sınaması olacaktır. 


\section{KAYNAKÇA}

Avrupa Birliği Bakanlığı ve TÜBİTAK. 2016. “Avrupa Birliği Horizon 2020 Programı”, https://www.ab.gov.tr/files/SBYPB/birlik\%20programlari/horizon_2020_programi.pdf (01.10.2019).

Benedetto, Giacomo ve Milio, Simona (Ed.). 2012. European Unions Budget Reform: Institutions, Policy and Economic Crisis, Palgrave Macmillan.

Bilici, Nurettin. 2005. Türkiye-AB İlişkileri (Genel Bilgiler, İktisadi-Mali Konular, Vergilendirme), Seçkin Yayıncılık. Cengiz, Çağdaş. 2018. Döviz Kurları, Euro ve Türkiye Ekonomisi. Ankara: İmaj Yayınevi.

European Commission. 2012. "Own Resources for 2014-2020", https://www.consilium.europa.eu/en/policies/eubudgetary-system/eu-revenue-own-resources/2014-2020/ (01.10.2019).

European Commission. 2017a. "Future financing of the EU", The High Level Group set up jointly by the European Parliament, the Council and the European Commission Final Report, https://ec.europa.eu/info/about-europeancommission/eu-budget/how-it-works/long-term-planning/future-long-term-budget/en (01.10.2019).

European Commission. 2017b. "New Budgetary Instruments for a Stable Euro Area Within the Union Framework, COM (2017) 822". http://ec.europa.eu/transparency/regdoc/rep/1/2017/EN (01.10.2019).

European Commission. 2017c. "Statement of President Juncker on the Proclamation of the European Pillar of Social Rights". https://ec.europa.eu/cyprus/news/20171117_en (01.10.2019).

European Commission. 2017d. "Moving forward on the European Pillar of Social Rights: Commission seeks to promote social protection for all". https://ec.europa.eu/cyprus/news/20171120_3_en (01.10.2019).

European Commission. 2018a. "Accompanying Staff Working Document, Spending Review, SWD (2018) 171", https://eur-lex.europa.eu/legal-content/EN/TXT/?uri=SWD:2018:171: FIN (01.10.2019).

European Commission. 2018b. "A Modern Budget for a Union that Protects, Empowers and Defends: The Multiannual Financial Framework for 2021-2027, COM/2018/321”. https://eur-lex.europa.eu/ (01.10.2019).

European Commission. 2018c. "Report of the Independent High Level Group on Maximising the Impact of EU Research and Innovation Programmes". https://ec.europa.eu/transparency/regdoc/rep/1/2018/EN (01.10.2019).

European Commission. 2018d. "Proposal for a Decision of the European Parliament and of the Counc1l on Establishing the specific programme implementing Horizon Europe - the Framework Programme for Research and Innovation, 2018/0225 (COD)". https://eur-lex.europa.eu/resource.html?uri=cellar:7cc790e8-6a33-11e8-948301aa75ed71a1.0002.03/DOC_1\&format=PDF (01.10.2019).

European Commission. 2018e. "Proposal for a Council Decision on the System of Own Resources of the European Union, $\operatorname{COM}(2018) \quad 325$ final”, https://ec.europa.eu/commission/sites/beta-political/files/system-own-resourcesmay2018_en.pdf (01.10.2019).

European Commission. 2018f. "Proposal for a Council Regulation Laying Down Implementing Measures for the System of Own Resources of the European Union, COM(2018)327/F1. https://eur-lex.europa.eu/ (01.10.2019).

European Commission. 2019a. "A 'No-Deal' Brexit: The EU Budget". https://ec.europa.eu/info/sites/info/files/factsheet_budget_contingency_final.pdf (01.10.2019).

European Commission. 2019b. "EU Budget Own Resources". https://ec.europa.eu/info/strategy/eu-budget/revenue/ownresources_en\#own_res (01.10.2019).

European Council. 2014. "Own Resources for 2014-2020”. https://www.consilium.europa.eu/en/policies/eu-budgetarysystem/eu-revenue-own-resources/2014-2020/ (01.10.2019).

European Council. 2019. "Multiannual financial framework: shaping EU expenditure". https:// www.consilium.europa.eu/en/policies/eu-budgetary-system/multiannual-financial-framework/ (01.10.2019).

European Parliament. 2018. "Own resources of the European Union: Reforming the EU's Financing System". http://www.par12019ro.eu/eu/HTP_BLOB?id=3948\&tip=pdf\&blb=3 (01.10.2019).

European Parliament. 2019a. "2021-2027 multiannual financial framework and new own resources: Analysis of the Commission's proposal". http://www.epgencms.europarl.europa.eu/cmsdata/upload/db93fa39-84ce-44fe-b4fa4c6824185e13/2021-2027_Multiannual_financial_framework_and_new_own_resources_-

_Analysis_of_the_Commission's_proposal_.pdf (01.10.2019).

European Parliament. 2019b. "Legislative Training Schedule". http://www.europarl.europa.eu/legislative-train/themenew-boost-for-jobs-growth-and-investment/file-mff-2021-2027-mff (01.10.2019).

Güvenç, Müge H. 2010a. “Avrupa Birliği Bütçesi.” Maliye Bakanlığı Avrupa Birliği ve Dış İlişkiler Daire Başkanlığl Araştırma ve Inceleme Serisi I.

Güvenç, Müge H. 2010b. “Avrupa Birliği Bütçesi’nin Finansmanı: Öz Kaynaklar Sistemi”. Maliye Dergisi 158:513-530.

IKKV. 2004. Avrupa Birliği’nin Bütçesi ve Türkiye'deki Bütçe Sisteminin AB'ye Uyumu, İstanbul.

IKV. 2019. “2021-2027 Bütçe Döneminde AB’nin Bölgesel Politikasi”. İKV Değerlendirme Notu No: 223.

Keep, Matthew. 2019. "A Guide to the EU Budget", Briefing Paper No: 06455, House of Commons Library.

Kurtar, Adem ve Cengiz, Çağdaş. 2019. Avrupa Birliği 2021-2027 Bütçesi ve Türkiye. Ankara: İmaj Yayınevi.

London School of Economics and Political Science. 2018. "Aligning national and international climate targets" Grantham Institute, http://www.lse.ac.uk/GranthamInstitute/ (01.10.2019).

Schumpeter, Joseph A. 2010. Capitalism, Socialism and Democracy, Routledge Classics. 